\title{
Article \\ Estradiol Inhibits Human Brain Vascular Pericyte Migration Activity: A Functional and Transcriptomic Analysis
}

\author{
Lisa Kurmann ${ }^{1}$, Michal Okoniewski ${ }^{2}$ (D) and Raghvendra K. Dubey ${ }^{1,3, *(D)}$ \\ 1 Department of Reproductive Endocrinology, University Hospital Zurich, 8952 Schlieren, Switzerland; \\ lisa.kurmann@usz.ch \\ 2 ID Scientific IT Services, ETH Zurich, 8092 Zurich, Switzerland; michal.okoniewski@id.ethz.ch \\ 3 Department of Pharmacology \& Chemical Biology, University of Pittsburgh, Pittsburgh, PA 15219, USA \\ * Correspondence: raghvendra.dubey@usz.ch
}

Citation: Kurmann, L.; Okoniewski, M.; Dubey, R.K. Estradiol Inhibits Human Brain Vascular Pericyte Migration Activity: A Functional and Transcriptomic Analysis. Cells 2021, 10, 2314. https://doi.org/ $10.3390 /$ cells10092314

Academic Editor: Jessica Filosa

Received: 27 July 2021

Accepted: 1 September 2021

Published: 4 September 2021

Publisher's Note: MDPI stays neutral with regard to jurisdictional claims in published maps and institutional affiliations.

Copyright: (C) 2021 by the authors Licensee MDPI, Basel, Switzerland. This article is an open access article distributed under the terms and conditions of the Creative Commons Attribution (CC BY) license (https:/ / creativecommons.org/licenses/by/ $4.0 /)$.

\begin{abstract}
Stroke is the third leading cause of mortality in women and it kills twice as many women as breast cancer. A key role in the pathophysiology of stroke plays the disruption of the blood-brain barrier (BBB) within the neurovascular unit. While estrogen induces vascular protective actions, its influence on stroke remains unclear. Moreover, experiments assessing its impact on endothelial cells to induce barrier integrity are non-conclusive. Since pericytes play an active role in regulating BBB integrity and function, we hypothesize that estradiol may influence BBB by regulating their activity. In this study using human brain vascular pericytes (HBVPs) we investigated the impact of estradiol on key pericyte functions known to influence BBB integrity. HBVPs expressed estrogen receptors (ER- $\alpha, E R-\beta$ and GPER) and treatment with estradiol $(10 \mathrm{nM})$ inhibited basal cell migration but not proliferation. Since pericyte migration is a hallmark for BBB disruption following injury, infection and inflammation, we investigated the effects of estradiol on TNF $\alpha$-induced PC migration. Importantly, estradiol prevented TNF $\alpha$-induced pericyte migration and this effect was mimicked by PPT (ER- $\alpha$ agonist) and DPN (ER- $\beta$ agonist), but not by G1 (GPR30 agonist). The modulatory effects of estradiol were abrogated by MPP and PHTPP, selective ER- $\alpha$ and ER- $\beta$ antagonists, respectively, confirming the role of ER- $\alpha$ and ER- $\beta$ in mediating the anti-migratory actions of estrogen. To delineate the intracellular mechanisms mediating the inhibitory actions of estradiol on PC migration, we investigated the role of AKT and MAPK activation. While estradiol consistently reduced the TNF $\alpha$-induced MAPK and Akt phosphorylation, only the inhibition of MAPK, but not Akt, significantly abrogated the migratory actions of TNF $\alpha$. In transendothelial electrical resistance measurements, estradiol induced barrier function (TEER) in human brain microvascular endothelial cells co-cultured with pericytes, but not in HBMECs cultured alone. Importantly, transcriptomics analysis of genes modulated by estradiol in pericytes showed downregulation of genes known to increase cell migration and upregulation of genes known to inhibit cell migration. Taken together, our findings provide the first evidence that estradiol modulates pericyte activity and thereby improves endothelial integrity.
\end{abstract}

Keywords: estrogen receptor; MAPK; TNF $\alpha$; blood-brain barrier; stroke; inflammation; COVID-19

\section{Introduction}

Stroke is a major contributor for mortality and disability in women [1] and a burden often overlooked compared to cancer. The overall risk for developing a stroke is higher in women compared to men [2]. Moreover, a dramatic increase in stroke events is largely observed in women after menopause, whereas the risk in premenopausal women is relatively lower compared to age-matched men [2]. These findings, together with the fact that estradiol levels drop following menopause, have led to the hypothesis that estradiol may be protective and may contribute to the sexual dimorphism in cardiovascular diseases, including stroke. Estrogen plays an important role in regulating dynamic changes in vascular structure and function and, importantly, it protects against vascular remodeling 
associated with coronary artery disease and endothelial injury [3,4]. Apart from being vaso-protective, estrogen is also known to induce neuroprotective actions by preventing uncontrolled neuroinflammation and excessive ROS production. The blood-brain barrier (BBB) is critical for homeostasis of the central nervous system, and BBB disruption is an important aspect in stroke incidents [5]. A widely accepted hypothesis is that estrogen's protective function is, in part, attributed to the maintenance of endothelial barrier integrity [6-10]. In in vivo animal studies estradiol has largely been shown to protect against injury and ischemic stroke associated capillary leakage and brain damage $[6,10,11]$. However, conclusive evidence for estrogen mediated BBB protection is lacking, as both, protective and deleterious actions of estrogen on brain capillary endothelial barrier as well as pro-inflammatory action of the hormone have been observed in vitro [12-15]. Moreover, increased incidents of stroke were also noticed in postmenopausal women taking estrogen replacement therapy [1]. Hence, the overall effects of estradiol on BBB and the underlying mechanism(s) remain inconclusive and require in-depth investigation.

Proper functioning of a dynamic barrier at the blood-brain interface requires highly regulated mechanisms [16]. Although, capillary endothelial cells were long considered to be responsible for BBB integrity, it is now clear that the formation of the BBB is orchestrated by a complex network of different cell types, which together form the neurovascular unit (NVU). In this context, pericytes (PCs), which are located next to a single layer of capillary endothelial cells (ECs) as well as astrocytes, neurons, glial cells and extracellular matrix components contribute to the functional integrity of the BBB [17-20]. PCs have gained increasing attention in recent years. As vascular mural cells, PCs share the same basement membrane with ECs. They are thought to stem from the same cell lineage as vascular smooth muscle cells (VSMCs) but exhibit important differences with regard to their location in the vasculature, their morphology and function [21-23]. Several studies using viable PC-deficient mouse models have demonstrated that reduced PC coverage leads to vascular leakage and brain edema $[17,18]$, thereby shedding new light on the importance of pericyte's in promoting endothelial integrity. Moreover, PC loss is a hallmark of many central nervous system disorders like Alzheimer's disease, stroke and multiple sclerosis, to name a few [23-27]. Importantly, the migration of PCs away from the endothelial layer is a critical manifestation of cerebral ischemia and correlates with barrier leakage and break down after stroke, but also in other pathologies like brain trauma, viral infection, sepsis and diabetic retinopathy [28-31]. Following injury/insult, release of pro-inflammatory cytokines, such as TNF $\alpha$, have been shown to be a prominent inducer of PC migration in vitro [32,33]. TNF $\alpha$ is also a well-known mediator of vascular dysfunction, and its up-regulation under inflammatory conditions as well as in the plasma of ischemic stroke patients has been shown repeatedly and even correlates with stroke damage and lesion size $[34,35]$.

Based the observations that: in in vivo studies in animals, estradiol is protective against $\mathrm{BBB}$ disruption in various models; in in vitro studies using endothelial cell monolayers as a model for BBB function, estradiol has inconclusive actions with protective, deleterious as well as neutral effects; pericytes presence is essential for a functional BBB; following injury (trauma or stroke etc.) PC migration away from the endothelial lining occurs and is a hallmark for BBB disruption; estradiol inhibits migration of SMCs, which are phenotypically similar to pericytes, we hypothesize that estradiol may mediate its protective actions on BBB by modulating PC activity and inhibiting their migration. Indeed, while estrogen action on ECs and SMCs has been extensively investigated [36], its modulatory role in PCs remains unexplored. Since PCs are phenotypically similar to VSMCs as well as the fact that PC degeneration is associated with aging [37], it is feasible that estradiol might also influence PC function. More specifically, we were interested in investigating the effects of estradiol on growth and migration of PCs, and delineating the underlying mechanisms, including estrogen receptor (ER) $-\alpha,-\beta$ and GPER, as well as protein kinases MAPK and Akt. Furthermore, using PCs co-cultured with endothelial cells, we assessed whether estradiol improves barrier function. To get an in-depth understanding and shed light on the 
mechanism(s) that may be triggered by estradiol, we analyzed estradiol-induced changes in mono- and co-cultured PCs using transcriptomic analysis.

\section{Materials and Methods}

\subsection{Cell Culture}

hBVPs: Human Brain Vascular Pericytes (HBVPs, ScienCell, Carlsbad, CA, USA) between the 4th and 10th passage were cultured as described previously [38]. Briefly, hBVPs were grown in flasks coated with Poly-L-Lysine (PLL; $2 \mu \mathrm{g} / \mathrm{cm}^{2}$ ) under standard tissue culture conditions $\left(37^{\circ} \mathrm{C}, 5 \% \mathrm{CO}_{2}\right.$ ) in pericyte growing media (DMEM/F12 supplemented with antibiotic-antimycotic (AA; $100 \mu \mathrm{g} / \mathrm{mL}$ streptomycin, $100 \mu \mathrm{g} / \mathrm{mL}$ penicillin and $0.025 \mu \mathrm{g} / \mathrm{mL}$ amphotericin B), Glutamax $(1 \times)$ and $10 \%$ FBS). The cells were cultured until sub-confluency and media was changed every two or three days.

hCMEC/D3: The human Cerebral Microvascular Endothelial Cell line (hCMEC/D3) [39] was kindly provided by Dr. Pierre-Olivier Couraud (Institute COCHIN, Paris, France). Cells between the 34th and 39th passage were cultured as described before [38] on rattail-collagen-coated $(250 \mu \mathrm{g} / \mathrm{mL}$ in $80 \% \mathrm{EtOH})$ flasks under standard tissue culture conditions $\left(37^{\circ} \mathrm{C}, 5 \% \mathrm{CO}_{2}\right.$ ) in complete growing media (EC basal media (EndoGRO Basal Medium supplemented with $0.2 \%$ EndoGRO-LS Supplement, $5 \mathrm{ng} / \mathrm{mL} \mathrm{rh}$ EGF, $4 \mathrm{mM}$ L-Glutamine, $0.75 \mathrm{U} / \mathrm{mL}$ Heparin Sulfate, $50 \mu \mathrm{g} / \mathrm{mL}$ Ascorbic Acid, $1 \mathrm{ng} / \mathrm{mL}$ bFGF, antibiotic-antimycotic $(100 \mu \mathrm{g} / \mathrm{mL}$ streptomycin, $100 \mu \mathrm{g} / \mathrm{mL}$ penicillin and $0.025 \mu \mathrm{g} / \mathrm{mL}$ amphotericin B) supplemented with 5\% FBS. Media was changed every two or three days and cells were passaged after confluency was reached.

\subsection{Cell Count}

hBVPs were plated in PLL-coated 24-wellplates in PC growing media at a density of 5000 cells $/ \mathrm{cm}^{2}$ and let to attach for $24 \mathrm{~h}$. Cells were growth arrested $\mathrm{o} / \mathrm{n}$ in starving media (DMEM/F12 supplemented with AA $(100 \mu \mathrm{g} / \mathrm{mL}$ streptomycin, $100 \mu \mathrm{g} / \mathrm{mL}$ penicillin and $0.025 \mu \mathrm{g} / \mathrm{mL}$ amphotericin B), GlutaMAX $(1 \times)$ and $0.5 \%$ sf. FCS) for 3 days. Thereafter cells were washed twice, with HBSS $\left(-\mathrm{Mg}^{2+}-\mathrm{Ca}^{2+}\right)$, trypsinized with trypsin $(0.5 \%)$ and counted with a Coulter Counter (Coulter Z1, Coulter Electronics, Luton, UK). Relative cell number was assessed by normalizing to control.

\subsection{Migration Studies}

Migration of cells was assessed by a scratch-/wound-closure-assay. Cells were plated in PLL-coated 24-wellplates and grown to confluence. Cells were starved o/n in starving media (DMEM/F12 supplemented with AA $(100 \mu \mathrm{g} / \mathrm{mL}$ streptomycin, $100 \mu \mathrm{g} / \mathrm{mL}$ penicillin and $0.025 \mu \mathrm{g} / \mathrm{mL}$ amphotericin B), GlutaMAX (1×) and 0.5\% (sf.) FCS). If required, cells were pre-treated with antagonists/inhibitors for the assigned period of time, before the monolayers were scratched with a yellow pipette tip. Cells were washed once with HBSS $\left(+\mathrm{Mg}^{2+}+\mathrm{Ca}^{2+}\right)$ to remove loose cells, and treatment or vehicle was added. Images of each scratch were taken with an automated Olympus IX81 microscope (Olympus, Volketswil, Switzerland) at $0 \mathrm{~h}$ and at $10 \mathrm{~h}$ after treatment. Area of wound closure was determined by using the software ImageJ, and relative wound closure was calculated as follows: (area(T0)-area(T10))/area(T0). A schematic representation of the experimental set-up is provided in Figure S1.

\subsection{Western Blot Analysis}

For Western blot analysis, cells were grown in $35 \mathrm{~mm}$ dishes and treated as specified. For lysis, cells were washed briefly with ice-cold HBSS $\left(+\mathrm{Mg}^{2+}+\mathrm{Ca}^{2+}\right)$ before lysis buffer (containing $20 \mathrm{mM}$ Tris pH 7.5, 1\% Triton X- 100, $150 \mathrm{mM} \mathrm{NaCl}, 1 \mathrm{mM}$ EGTA, $1 \mathrm{mM}$ EDTA, $2.5 \mathrm{mM}$ sodium phosphate, $1 \mathrm{mM} \beta$-glycerophosphate, $1 \mathrm{mM}$ sodium vanadate, 0.5 PMSF and $0.2 \%$ SDS) was added for $2 \mathrm{~min}$ on ice. Cell lysates were collected by scraping and samples were frozen at $-80^{\circ} \mathrm{C}$ until further processing. Concentration of each sample was determined with the Pierce bicinchoninic acid (BCA) Assay Kit according 
to the manufacturer's protocol. Equivalent amounts $(10 \mu \mathrm{g})$ of protein from whole-cell lysates were separated on $8 \%, 10 \%$ or $12.5 \%$ SDS-polyacrylamide gels. As a marker, Protein Marker Enhanced 3-color High Range or Precision Plus Dual Color Standard was used. After transfer to a nitrocellulose membrane by the method of wet electroblotting, the membrane was blocked with $5 \%$ milk at RT for $1 \mathrm{~h}$. Incubation with the primary antibody was performed $\mathrm{o} / \mathrm{n}$ at $4{ }^{\circ} \mathrm{C}$. After washing, the membrane was incubated with the secondary antibody for $1 \mathrm{~h}$ at RT and washed again. For detection of proteins with IR Dyes, the Odyssey LI-COR system (LI-COR, Lincoln, NE, USA) was used. For peroxidaseconjugated secondary antibodies, chemiluminescent substrates (Pierce, Rockford, IL, USA) were added according to manufacturer's instruction. Peroxidase activity was detected by exposing the membranes to XOMAT LS films, which were developed with the CAWOMAT 2000 IR film developer (WIROMA AG, Niederscherli, Switzerland).

\subsection{Transendothelial Electric Resistance (TEER)}

For TEER measurements in real-time, a cellZscope instrument (nanoAnalytics $\mathrm{GmbH}$, Münster, Germany) was used. Permeable transparent PET membrane inserts of $0.4 \mu \mathrm{m}$ pore size and 24-well format (Falcon 353095) were coated with poly-L-Lysine on the basolateral side and with rat tail collagen $(250 \mu \mathrm{g} / \mathrm{mL}$ in $80 \% \mathrm{EtOH})$ on the apical side for $1 \mathrm{~h}$ at $37^{\circ} \mathrm{C}$ and washed twice with sterile $\mathrm{H}_{2} \mathrm{O}$, before they were incubated for another hour in PC growing media ( $5 \%$ FBS). For the co-culture models, hBVPs were seeded either on the basolateral or on the apical side of the insert at a density of 25,000 cells $/ \mathrm{cm}^{2}$. After adherence of the PCs was achieved $(3 \mathrm{~h})$, hCMEC/D3 were seeded in the apical chamber at a cell density of 100,000 cells $/ \mathrm{cm}^{2}$ in $150 \mu \mathrm{L}$ EndoGro growing media. Media in the basolateral chamber consisted of PC growing media ( $5 \%$ FBS). After 3 days, media was changed to $2 \%$ sf.FBS and hydrocortisone $(1 \mu \mathrm{g} / \mathrm{mL})$ was added. For measurements, inserts were added to the cellZscope instrument (lower chamber: $1 \mathrm{~mL}$ media, upper chamber: $0.5 \mathrm{~mL}$ media). Establishment of a proper barrier function was monitored by recording resistance values of the inserts every hour, and treatments were only applied once the cells reached a stable baseline. All measurements were normalized to the values of a coated insert without any cells and results are depicted in \% of control or in absolute TEER values in ohm $\times \mathrm{cm}^{2}$.

\subsection{Microarray}

Microarray samples were prepared as described previously [38]: PCs were seeded alone or with ECs on the opposite side of permeable PET membrane inserts of $0.4 \mu \mathrm{m}$ pore size and six-well format (Corning Incorporated, Corning, NY, USA, Costar 3450) as described above. After 5 days in culture ( $2 \%$ steroid-free FCS (charcoal-stripped) in presence of hydrocortisone), cells were treated with estradiol $(10 \mathrm{nM})$ or vehicle for $48 \mathrm{~h}$. Cells were then trypsinized, centrifuged and lysed in $300 \mu \mathrm{L}$ RNA lysis buffer (Zymo Research, Irvine, CA, USA). Samples were frozen at $-80^{\circ} \mathrm{C}$ until further processing. Total RNA was extracted by using the Quick-RNA MiniPrep Kit (ZymoResearch, Irvine, CA, USA, R1055) according to the manufacture's protocol with a 5417R Centrifuge (Eppendorf, Hamburg, Germany). RNA integrity was checked by calculating the ratio of absorbance at $260 / 280 \mathrm{~nm}(>2.0)$ and $260 / 230 \mathrm{~nm}(>1.8)$. The samples were frozen at $-80^{\circ} \mathrm{C}$. Microarray analysis using Affymetrix Clariom S Assay, human (Applied Biosystems by Thermo Fisher Scientific Inc, Waltham, MA, USA, 902927) was performed as previously described [40]. For transcriptome analysis, fragmented biotin-labeled ds cDNA was hybridized to ClariomTM S arrays (ClariomTM S arrays, human). After staining, arrays were scanned with Affymetrix Gene-Chip Scanner-3000-7G (Applied Biosystems by Thermo Fisher Scientific Inc, Waltham, MA, USA) while quality control analysis was performed using GeneChip Command Console Software (GCC) v5.0. Transcriptome analysis was performed at the transcriptomics core facility at the Center for Molecular Medicine Cologne (CMMC). Differentially regulated genes were determined with the Transcriptome Analysis Console (TAC, Applied Biosystems by Thermo Fisher Scientific Inc., Waltham, MA, USA) after 
uploading the CEL files, based on a fold change cut-off of $+/-1.5$ (Log2 FC +/ -0.59$)$ and FDR $p$-value of 0.05 . The microarray data are deposited in the public Gene Expression Omnibus (GEO) database under the accession no. GSE168514 (Available online: www.ncbi.nlm.nih.gov / geo/ query/acc.cgi?acc=GSE168514) (accessed on 20 July 2021).

\subsection{Statistical Analysis}

Experiments were performed at least 3 times and data are represented as mean $+/-$ SD unless stated otherwise. Statistical evaluation was performed by using R. If ANOVA assumptions were met, parametric testing was performed with one-way ANOVA and subsequent Tukey's HSD multiple pairwise comparisons. If either one of the ANOVA assumptions were not met, non-parametric testing was performed with Kruskal-Wallis rank sum test and subsequent pairwise Wilcoxon-test with Benjamini \& Hochberg corrections for multiple comparisons.

\section{Results}

\subsection{Estradiol Inhibits Migration of Pericytes but Has No Impact on Proliferation}

When we looked at PC proliferation after estradiol (E2) treatment, no significant effect was observed (Figure S2a). As a positive control, we used fetal bovine serum (FBS) (2\% and $5 \%)$ and platelet-derived growth factor (PDGF) -BB $(20 \mathrm{ng} / \mathrm{mL})$ and all of them significantly increased cell number from $100 \%$ to $201 \%$ (FBS $2 \%, p<0.0001$ ), to $444 \%$ (FBS 5\%, $p<0.0001$ ) and to $178 \%$ (PDGF, $p<0.0001$ ), respectively (Figure S2b). Furthermore, the possibility of opposing effects of the different ERs was tested by using ER-agonists. Neither of the used agonists PPT (ER- $\alpha$-agonist), DPN (ER- $\beta$-agonist) and G-1 (GPER-agonist) significantly changed the proliferation of pericytes (Figure S2c).

To further investigate estradiol's action on PC function, scratch-wound assays were performed in presence of different concentrations of estradiol. The results showed an inhibition of migration at all considered concentrations of E2 by $30 \%\left(10^{-7} \mathrm{M}\right), 32 \%\left(10^{-8} \mathrm{M}\right)$ and $34 \%\left(10^{-9} \mathrm{M}\right.$, all $\left.p<0.0001\right)$ (Figure 1$)$. PDGF-BB $(20 \mathrm{ng} / \mathrm{mL})$ and FBS $(2 \%)$ were used as positive controls and increased migration by $59 \%$ and by $50 \%$, respectively (both $p<0.0001$ ) (Figure S3).

\subsection{Brain Pericytes Express All Three Estrogen Receptors}

To assess whether inhibitory effects of estrogen on PC migration were ER mediated, the expression of estrogen receptors (ERs) in pericytes (PCs) was verified by Western blotting. As shown in Figure 2a, all three ERs (ER-alpha, ER-beta and GPER) are well expressed in brain PCs. The estimated molecular weights of the receptors are $66 \mathrm{kDa}$ for ER-alpha, $58 \mathrm{kDa}$ for ER-beta and $42 \mathrm{kDa}$ for the G-protein coupled ER (GPER). Importantly, as shown in the dot plot and representative contrast enhanced photomicrographs, blocking of ERs by pretreating the cells with the non-selective ER-antagonist ICI 182780 completely abrogated the effects of E2 on PC migration (Figure $2 b, c$ ).

\subsection{Estradiol Attenuates Tumor Necrosis Factor Alpha (TNF $\alpha)$-Induced Migration of PCs}

Several studies have shown that following stroke and other brain injuries PCs migrate away from the BBB [30,41,42]. The inflammatory mediator tumor necrosis factor alpha $(\mathrm{TNF} \alpha)$ is one of the prominent cytokines known to be upregulated after stroke and is related to BBB break-down, as observed by us and many others [34,43] (Figure S4). Since $\mathrm{TNF} \alpha$ has also been shown to increase PC migration in vitro [32,33], we investigated the effect of E2 on TNF $\alpha$-induced migration of PCs. After confirming the increase in $\mathrm{PC}$ migration upon $\mathrm{TNF} \alpha$ treatment at several concentrations $(0.1 \mathrm{ng} / \mathrm{mL}-10 \mathrm{ng} / \mathrm{mL})$ (Figure S5), we further applied E2 treatment in combination with TNF $\alpha(10 \mathrm{ng} / \mathrm{mL})$. E2 treatment reduced TNF $\alpha$-induced migration of PCs from $161 \%(p<0.0001)$ back to basal levels of $93 \%(p<0.0001)$ (Figure 3). 


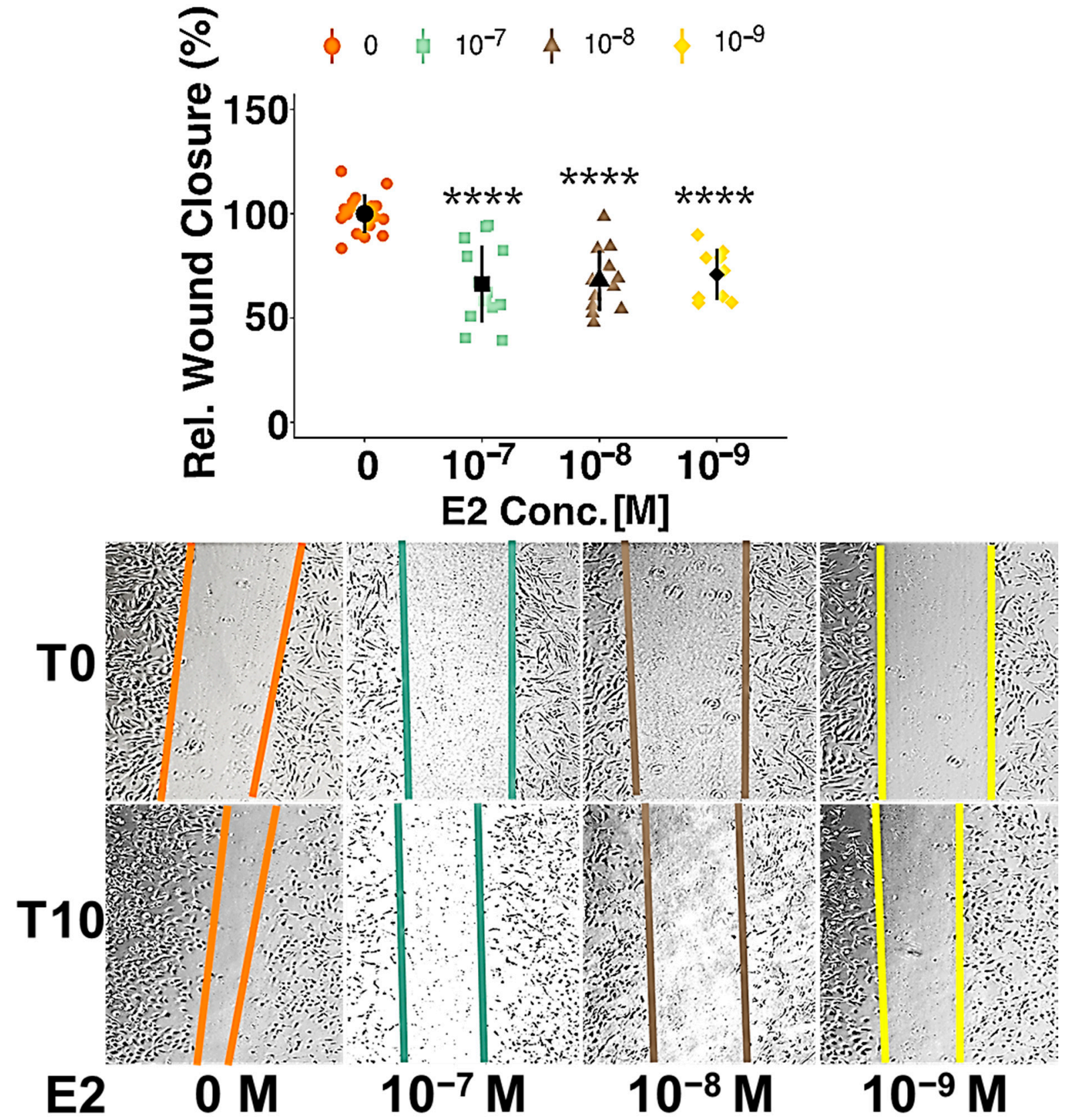

Figure 1. Estradiol inhibits pericyte (PC) migration. Cell migration was assessed using wound healing assays in confluent PC monolayers. Cells were treated with different concentrations of E2 $\left(10^{-7}, 10^{-8}\right.$ and $\left.10^{-9} \mathrm{M}\right)$ after the scratch was induced and wound closure was determined after $10 \mathrm{~h}$. Representative images are shown for T0 and T10 for each condition Experiments were performed at least 3 times in triplicates and data represent mean $+/-$ sd. ${ }^{* * * *} p<0.0001$. "Rel.": Relative; "Conc.": Concentration.

\subsection{Involvement of Kinase Cascades}

In a next step, the molecular pathway underlying the inhibitory action of estrogen on PC migration was assessed by Western blot analysis and by using pharmacological inhibitors. E2 reduced TNF $\alpha$-induced phosphorylation of MAPK (at Thr202/Tyr204) from $200 \%(p<0.0001)$ back to $119 \%(p<0.05)$ and of AKT (at Ser473) from 164\% $(p<0.001)$ to $114 \%(p<0.05)$ (Figure $4 \mathrm{a}, \mathrm{b})$. By treating the cells with pharmacological inhibitors for the two kinases, only pMAPK inhibitor (PD 98059) prevented TNF $\alpha$-induced migration, whereas pAKT inhibition with triciribine (TCN) showed no inhibitory effect on PC migration (Figure 5a,b). To further confirm this finding, a pharmacological inhibitor 
for PI3K, which is an upstream kinase of AKT, was used. Pre-treatment with the PI3Kinhibitor LY0294002 also did not inhibit TNF $\alpha$-stimulated migration (Figure 6a). Importantly, AKT-phosphorylation was decreased by the applied concentrations of both, LY and TCN (Figure 6b).

(a)
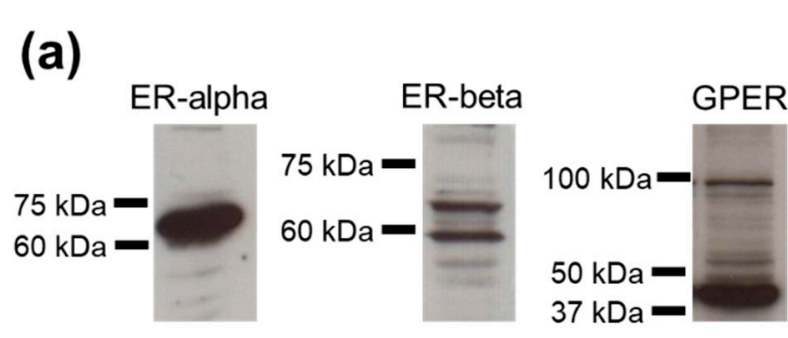

(b)

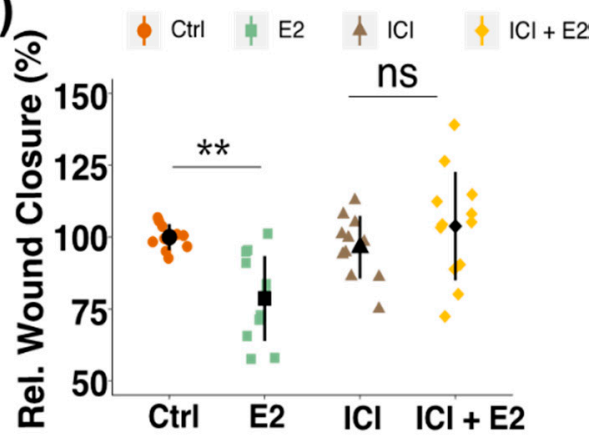

(c)

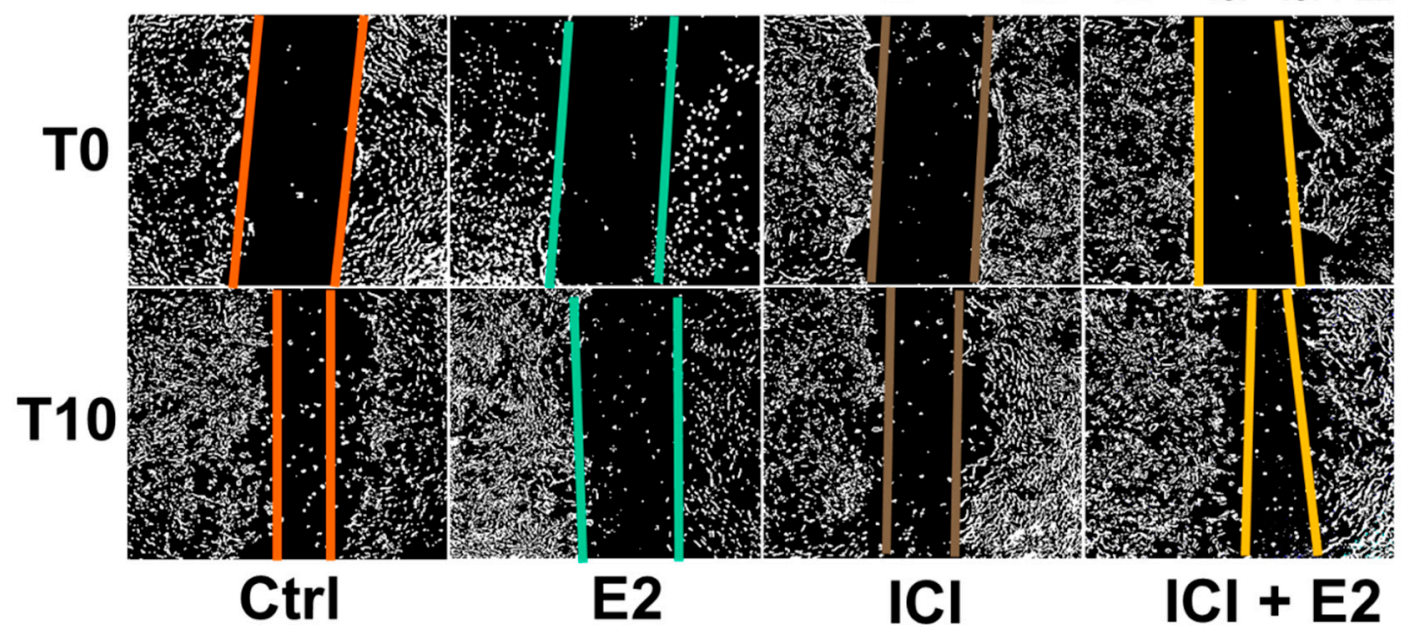

Figure 2. Pericytes (PCs) express all three estrogen receptors (ERs) and mediate inhibitory actions of estradiol (E2) on PC migration. Western blots of PC whole cell lysates showing the presence of ER-alpha, ER-beta and G-protein-coupled ER (GPER) (a). Wound healing assays showing the role of ERs in mediating E2 actions on PC migration. The non-selective ER-antagonist ICI $182780\left(10^{-6} \mathrm{M}\right)$ or vehicle was applied for $30 \mathrm{~min}$ before making the scratch and cells were treated with E2 $\left(10^{-8} \mathrm{M}\right)$ or ICI $\left(10^{-6} \mathrm{M}\right)$ or E2 + ICI and compared to vehicle. Wound closure was assessed after $10 \mathrm{~h}(\mathbf{b})$. Representative contrast adjusted photomicrographs (for clarity) depicting wounds at T0 and T10 for each condition (c). Experiments were performed at least 3 times in triplicates and data represent mean $+/-$ sd. ns $p>0.05,{ }^{* *} p<0.01$. "Rel.": Relative.

\subsection{Involvement of Estrogen Receptors (ERs)}

To investigate which ER is responsible for the inhibitory effects of E2 on TNF $\alpha$-induced PC migration, we used selective ER-agonists and -antagonists. ER- $\alpha$-agonist PPT reduced TNF $\alpha$-induced migration from $143 \%$ to $107 \%(p<0.05)$ and ER- $\beta$-agonist DPN to $103 \%$ $(p<0.05)$, while no significant effect was observed with G-1, the selective agonist for GPER (Figure 7a,b). PPT and DPN mimicked the inhibitory effect of E2 and inhibited basal PC migration by $27 \%$ (PPT, $p<0.05$ ) and $32 \%$ (DPN, $p<0.01$ ) (Figure S6). To confirm the importance of ER- $\alpha$ and ER- $\beta$ in mediating the effects of estradiol on PC migration, we applied selective ER- $\alpha$ - and ER- $\beta$-antagonist. Both, MPP (ER- $\alpha$-antagonist) as well as PHTPP (ER- $\beta$-antagonist) abrogated the inhibitory effects of estradiol on PC migration (Figure S7). 


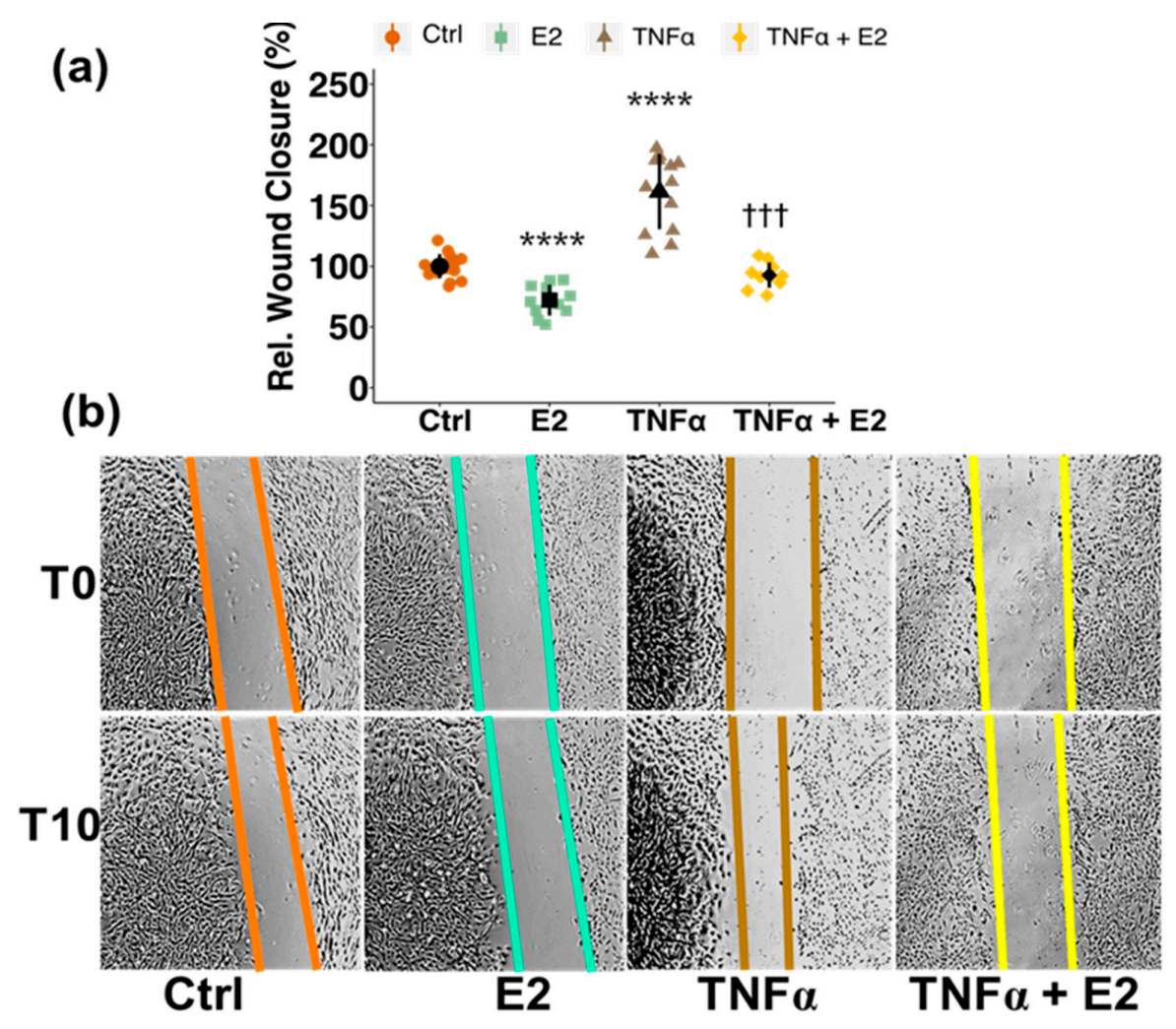

Figure 3. Estradiol (E2) inhibits $\mathrm{TNF} \alpha$-induced pericyte migration. Migration of pericytes was assessed using wound closure assay. After the scratch was made, cells were either treated with E2 $(10 \mathrm{nM}), \mathrm{TNF} \alpha(10 \mathrm{ng} / \mathrm{mL})$, a combination of the two or vehicle (Ctrl) (a). Wound closure was assessed after $10 \mathrm{~h}$ and representative images are shown at T0 and T10 (b). Experiments were performed 3 times in at least triplicates and data represent mean $+/-\mathrm{sd}$. ${ }^{* * * *} p<0.0001$, compared to Ctrl. +†† $p<0.001$, compared to TNF $\alpha$. "Rel.": Relative.
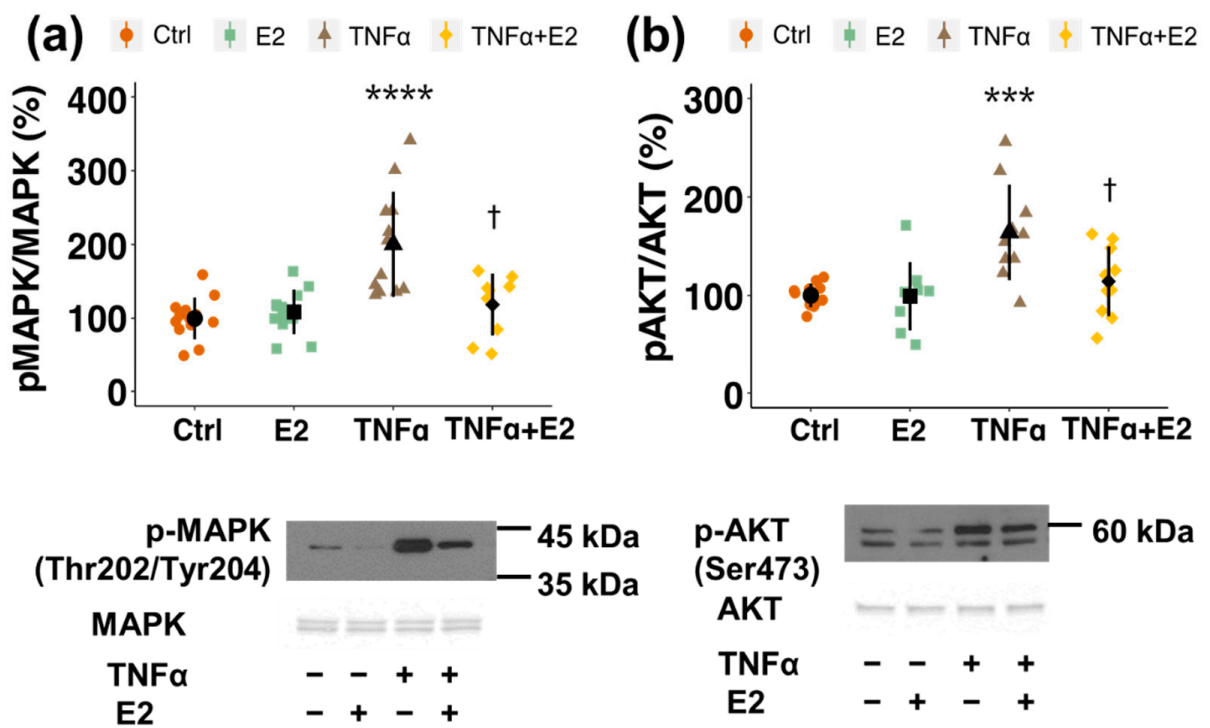

Figure 4. Estradiol (E2) inhibits TNF $\alpha$-induced phosphorylation of MAPK and AKT kinases. Western blot analysis was performed on whole cell lysates of pericytes treated with E2 $\left(10^{-8} \mathrm{M}\right), \mathrm{TNF} \alpha(10 \mathrm{ng} / \mathrm{mL})$, E2 plus TNF $\alpha$ or vehicle (Ctrl) for $6 \mathrm{~h}$. Representative Western blots of MAPK phosphorylation at Threonine residue 202 and Tyrosine residue 204 (a) and AKT phosphorylation at Serine residue 473 (b) are shown below the graph. Total MAPK and total AKT expression levels were taken for normalization. Experiments were performed 3 times in 3 to 5 replicates each and data represent mean $+/-$ sd. ${ }^{* * *} p<0.001,{ }^{* * * *} p<0.0001$, compared to Ctrl. $+p<0.05$ compared to TNF $\alpha$. 

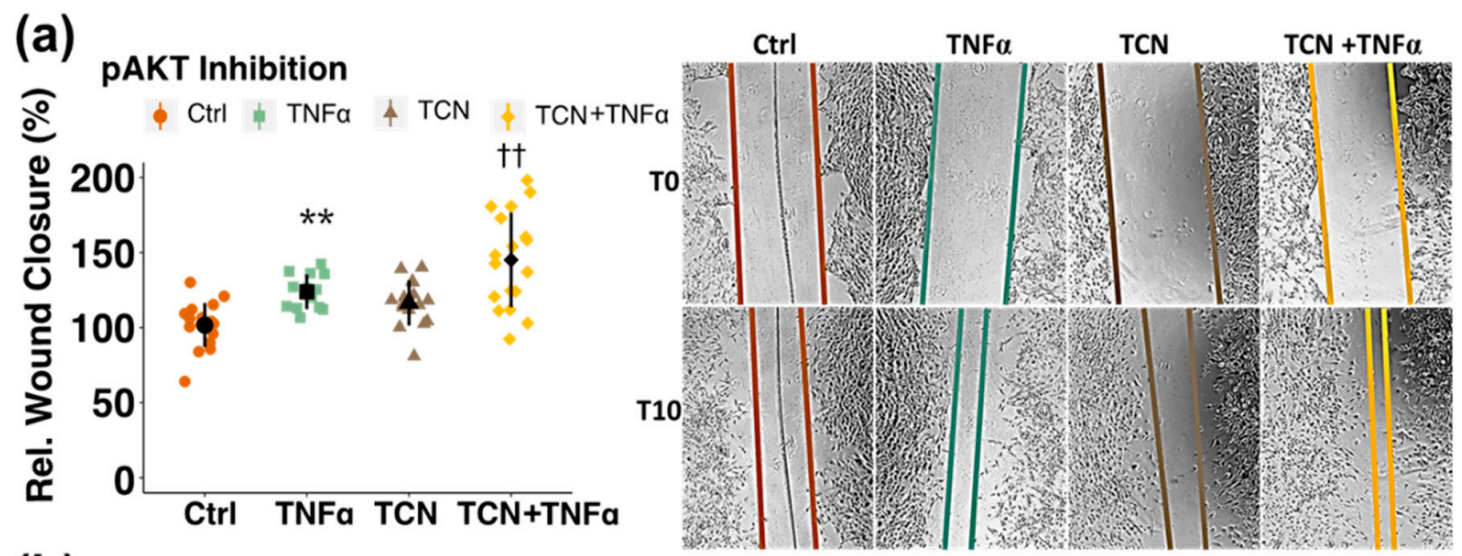

(b) pMAPK Inhibition
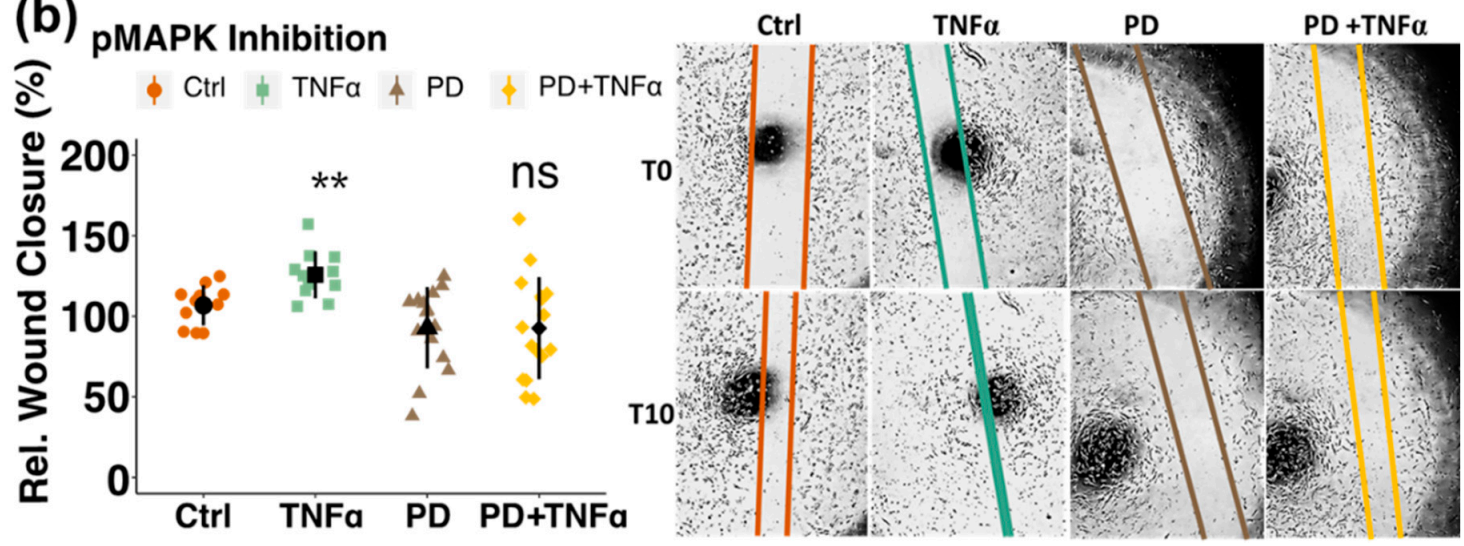

Figure 5. Estradiol (E2) inhibits TNF $\alpha$-induced pericyte migration by inhibiting pMAPK but not pAKT. Inhibition of pMAPK by pretreating the cells for 30 min with the pharmacological inhibitor PD $\left(10^{-5} \mathrm{M}\right)$ prevented TNF $\alpha$-induced increase in migration (b), whereas pretreatment with pAKT-inhibitor Triciribine (TCN, $\left.1.5 \times 10^{-6} \mathrm{M}\right)$ showed no effect (a). Representative images are shown at T0 and T10 on the right side of the graphs. Experiments were performed 3 times in 3 to 5 replicates each and data represent mean $+/-$ sd. ${ }^{* *} p<0.01$, compared to Ctrl. ns $p>0.05,++p<0.01$, compared to PD or TCN, respectively. "Rel.": Relative.

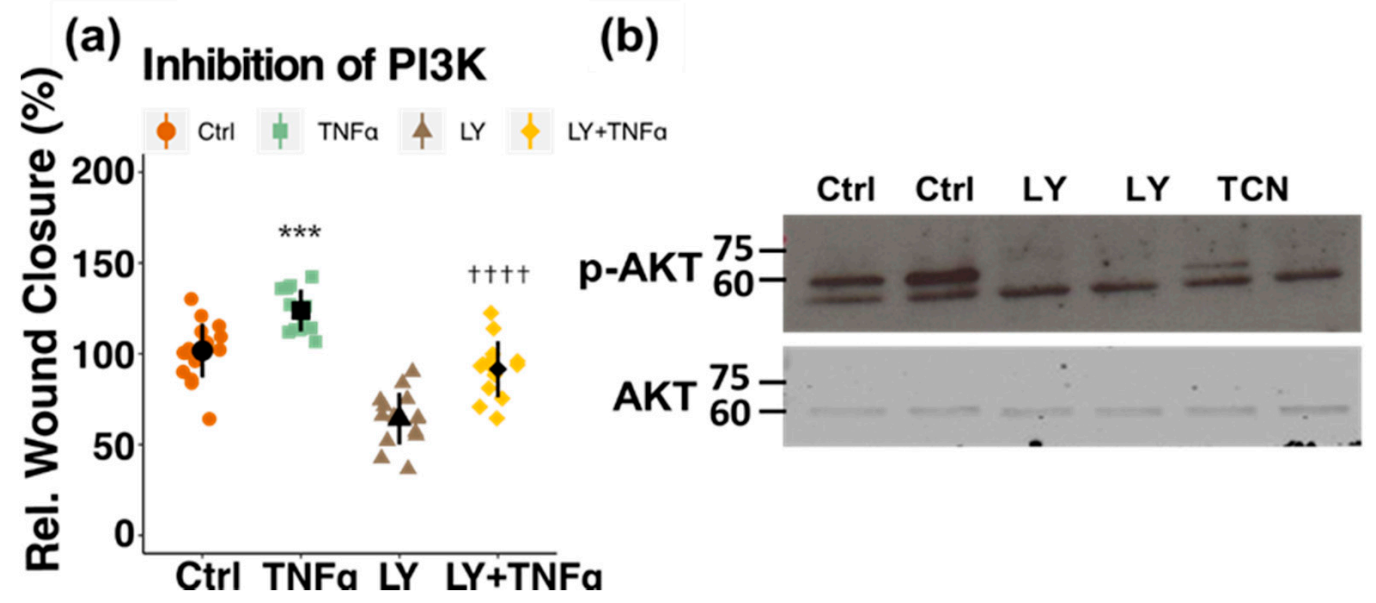

Figure 6. Inhibition of PI3K does not prevent TNF $\alpha$-induced migration in pericytes (PCs). PCs were pretreated for 30 min with the PI3K inhibitor LY0294002 (LY, $\left.5 \times 10^{-6} \mathrm{M}\right)$ or vehicle, before a scratch was induced and treatment with TNF $\alpha$ $(10 \mathrm{ng} / \mathrm{mL})$, LY or a combination of the two was added. The degree of migration was assessed after $10 \mathrm{~h}$ (a). Experiments were performed three times in 3 to 5 replicates each and data represents mean $+/-$ sd. ${ }^{* * *} p<0.001$, compared to Ctrl; t+†† $p<0.0001$, compared to LY. "Rel.": Relative. Treatment with the pharmacological inhibitors for AKT (Triciribine, TCN) and PI3K (LY0294002, LY) resulted in a decrease in AKT phosphorylation at Serine 473 (b). 


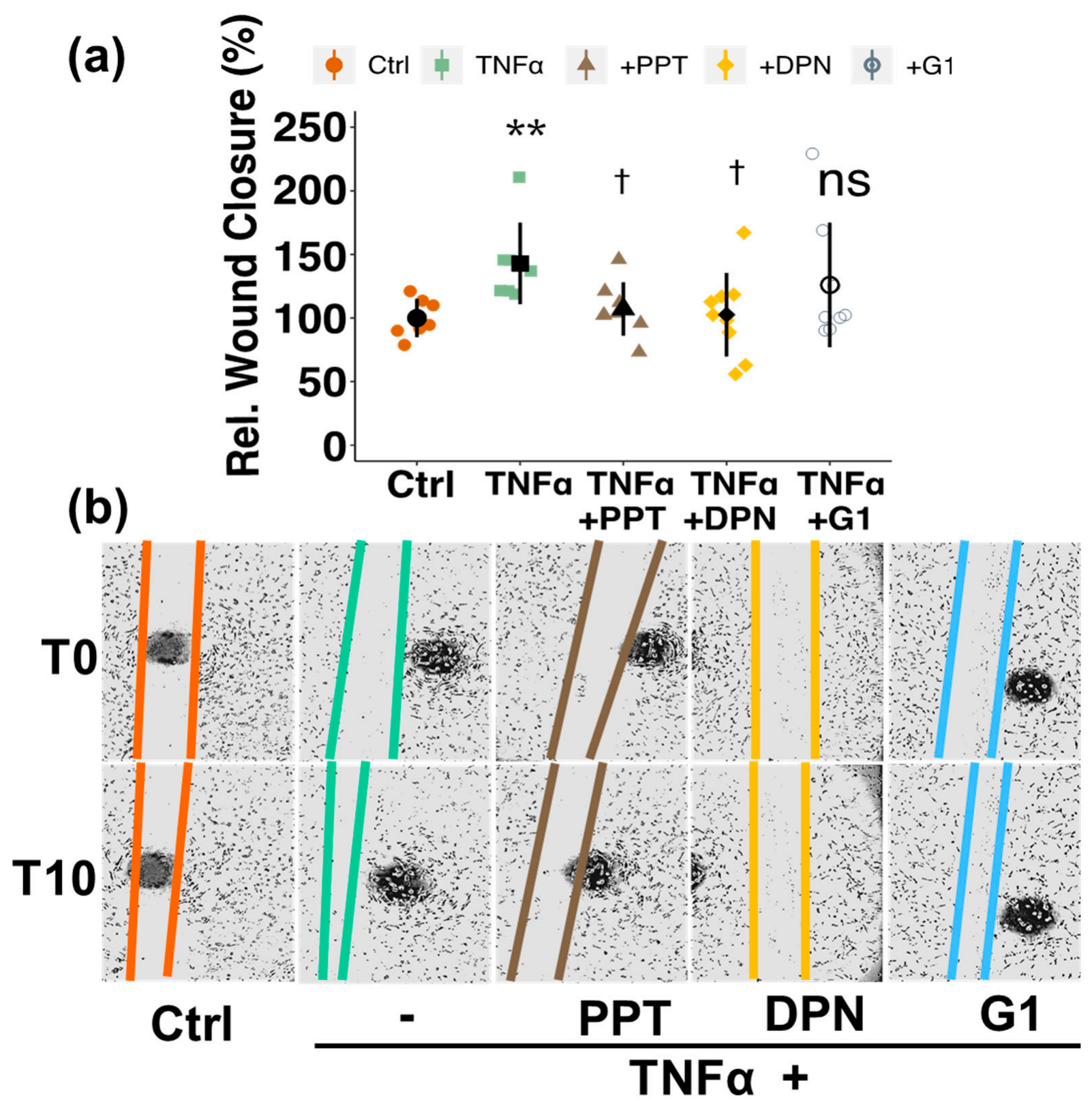

Figure 7. Estrogen receptor (ER)-alpha and ER-beta are responsible for estrogen-mediated downregulation of TNF $\alpha$-induced migration in pericytes (PCs). PCs were treated with agonists for ER- $\alpha$ (PPT), ER- $\beta$ (DPN) and GPER (G-1) $\left(10^{-7}\right.$ M) or vehicle in presence of TNF $\alpha(10 \mathrm{ng} / \mathrm{mL})$ after a scratch wound was induced (a). Relative wound closure was assessed after $10 \mathrm{~h}$ and representative images are shown on the right side of the graph for T0 and T10 (b). Experiments were performed 3 times in triplicates or duplicates and data represent mean $+/-$ sd. ${ }^{* *} p<0.01$, compared to Ctrl; ns $p>0.05,+p<0.05$, compared to TNF $\alpha$. "Rel.": Relative.

\subsection{Microarray Analysis of Estradiol Treated Pericytes}

In order to determine potential genes involved in our observation of decreased cell migration upon estradiol treatment in PCs, we conducted microarray analysis in E2 and vehicle treated PCs. We found 37 differentially regulated genes (DRGs), out of which 9 genes were up- and 28 genes were downregulated upon E2 treatment (Figure 8). A list of the top up- and downregulated genes can be found in the supplementary Tables S1 and S2. Submitting the expression data to pathway analysis yielded no statistically significant results. Interestingly, many of the E2-regulated genes are related to migration as well as metastasis formation in different cancer types (Table 1). 


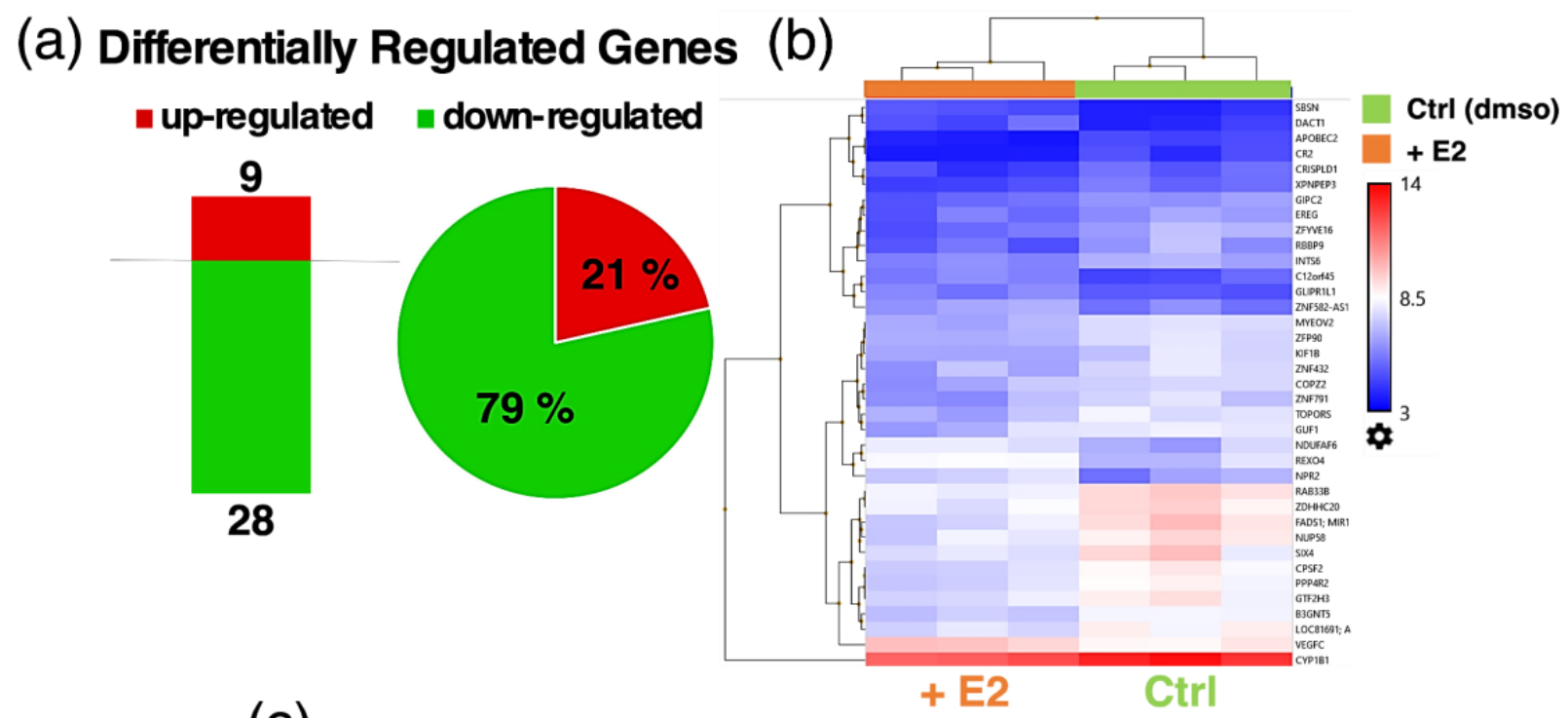

(c)

P-val vs. Fold Change

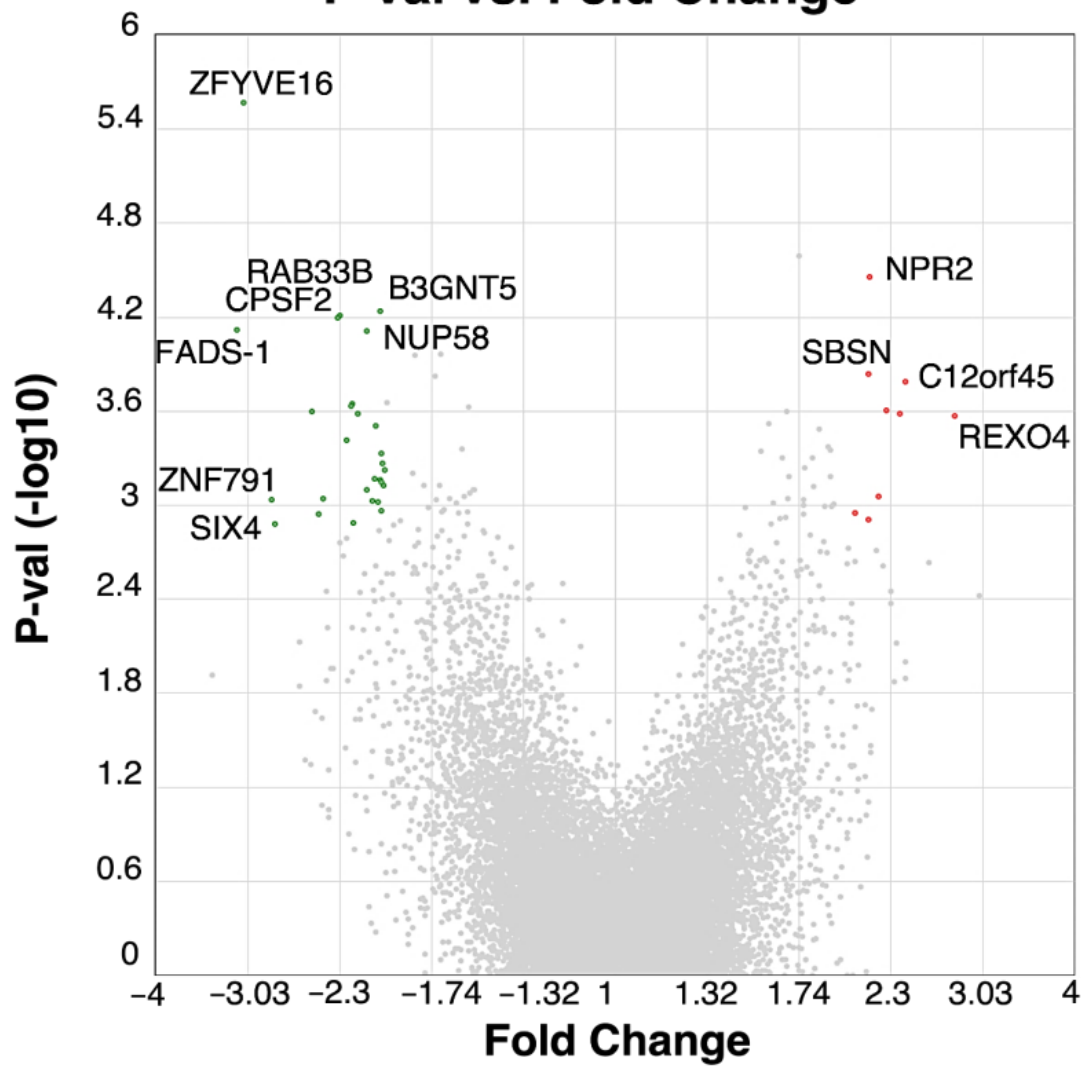

Figure 8. Differentially regulated genes (DRGs) in pericytes (PCs) treated with and without estradiol (E2, 10 $\left.{ }^{-8} \mathrm{M}\right)$. Number of DRGs and pie chart representation of up- and downregulated genes in \% of total number of DRGs (a). Heatmap representation of DRGs between E2- and vehicle (dmso) treated PCs (b). Volcano plot showing $p$-value $(-\log 10)$ on the $y$-axis vs. fold change of DRGs on the $x$-axis. Up- and downregulated genes are depicted in red and green, respectively and the most highly regulated genes are labeled (c). Color code: red-upregulated genes; green-downregulated genes. Transcriptome Analysis Console (TAC, Applied Biosystems by Thermo Fisher Scientific Inc., Waltham, MA, USA) was used for analyzing gene expression data of E2 treated vs. dmso treated PCs in triplicates. For the analysis, a fold change (FC) cut-off of $2(\log 2 \mathrm{FC}+/-1)$ and FDR $p$-Value of 0.34 was applied. 
Table 1. Differentially regulated genes in estradiol treated pericytes involved in migration and/or metastasis formation.

\begin{tabular}{|c|c|c|c|}
\hline Gene & Gene Description & $\begin{array}{c}\log 2 \text { FC } \\
\text { (Co- vs. } \\
\text { Mono-Culture) }\end{array}$ & FDR $p$-Value \\
\hline $\begin{array}{l}\text { FADS1 [44]; } \\
\text { MIR1908 [45] }\end{array}$ & $\begin{array}{l}\text { Fatty acid desaturase } 1 ; \\
\text { microRNA } 1908\end{array}$ & -3.1 & 0.208 \\
\hline ZFYVE16 [46,47] & $\begin{array}{l}\text { Zinc finger, FYVE domain } \\
\text { containing } 16\end{array}$ & -3.1 & 0.058 \\
\hline SIX4 [48] & SIX homeobox 4 & -2.8 & 0.333 \\
\hline RBBP9 [49] & Retinoblastoma binding protein 9 & -2.5 & 0.315 \\
\hline CPSF2 [50] & $\begin{array}{c}\text { Cleavage and polyadenylation specific } \\
\text { factor } 2\end{array}$ & -2.3 & 0.208 \\
\hline RAB33B [51] & $\begin{array}{l}\text { RAB33B, member RAS oncogene } \\
\text { family }\end{array}$ & -2.3 & 0.208 \\
\hline GUF1 [52] & GUF1 homolog, GTPase & -2.2 & 0.333 \\
\hline TOPORS $[53,54]$ & $\begin{array}{l}\text { Topoisomerase I binding, } \\
\text { arginine/serine-rich, E3 ubiquitin } \\
\text { protein ligase }\end{array}$ & -2.2 & 0.249 \\
\hline NUP58 [55] & Nucleoporin $58 \mathrm{kDa}$ & -2.1 & 0.208 \\
\hline PPP4R2 [56] & $\begin{array}{c}\text { Protein phosphatase } 4 \text {, regulatory } \\
\text { subunit } 2\end{array}$ & -2.1 & 0.315 \\
\hline EREG [57] & Epiregulin & -2.1 & 0.315 \\
\hline B3GNT5 [58] & $\begin{array}{l}\text { UDP-GlcNAc:betaGal beta-1,3-N- } \\
\text { acetylglucosaminyltransferase } 5\end{array}$ & -2.0 & 0.208 \\
\hline REXO4 $[59,60]$ & REX4 homolog, 3'-5' exonuclease & 2.8 & 0.249 \\
\hline NDUFAF6 [61] & $\begin{array}{l}\text { NADH dehydrogenase (ubiquinone) } \\
\text { complex I, assembly factor } 6\end{array}$ & 2.4 & 0.249 \\
\hline ZNF582-AS1 [62] & $\begin{array}{l}\text { ZNF582 antisense RNA } 1 \text { (head to } \\
\text { head) }\end{array}$ & 2.2 & 0.315 \\
\hline DACT1 [63] & $\begin{array}{l}\text { Dishevelled Binding Antagonist Of } \\
\text { Beta Catenin } 1\end{array}$ & 2.1 & 0.332 \\
\hline GLIPR1L1 [64] & GLI pathogenesis-related 1 like 1 & 2.1 & 0.315 \\
\hline
\end{tabular}

Fold changes (FC) and adjusted $p$-values (FDR $p$-value) are depicted in the third and fourth column, respectively. Transcriptome Analysis Console (TAC, Applied Biosystems) was used for analyzing gene expression data of E2 treated vs. dmso treated PCs in triplicates. For the analysis, a fold change (FC) cut-off of $+/-2$ and FDR $p$-Value of 0.34 was applied.

\subsection{Effect of Estradiol on Endothelial Barrier Function}

In order to demonstrate the importance of $\mathrm{E} 2$ action on the function of the $\mathrm{BBB}$, we also looked at the effect of E2 by means of barrier function studies with endothelial cells (ECs). We and others previously showed that co-culturing ECs and PCs on the opposite side of a permeable membrane in transwell inserts results in an increased barrier function [40,65-67]. Here, we assessed barrier function of ECs by measuring transendothelial electric resistance (TEER) in mono-cultured ECs and ECs co-cultured with PCs in presence or absence of E2. Interestingly, we found that TEER is increased upon E2 treatment in co-cultured ECs (by $17 \%, p<0.01$ ), whereas no effect of E2 was observed in endothelial monolayers (Figure 9).

\subsection{Microarray Analysis of Co-Cultured Pericytes Treated with Estradiol}

To investigate potential genes and underlying mechanisms that contribute to the observed increase in barrier function (TEER) after E2 treatment in ECs co-cultured with PCs, we performed different microarray analysis in co-cultured cells. While the changes induced by estradiol in mono- and co-cultured endothelial cells were minimal (supplementary Tables S3 and S4), we found a bigger impact of E2 in co-cultured PCs. A total of 15 DRGs was detected, with 13 thereof being up- and 2 being downregulated (Figure 10). The top up-and downregulated genes, when employing a FC +/ - cutoff of 2, are listed in supplementary Tables S5 and S6. Interestingly, some of these DRGs are involved in 
migration/metastasis (TARSL2, BEND6, HIST1H3I, HIST1H4D) as well as barrier function (BEND6) (Table 2).

\section{(a) EC only}

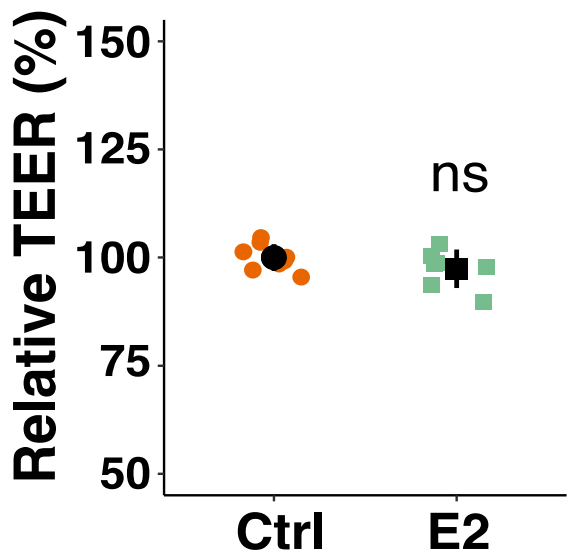

\section{(b) Co-Culture}

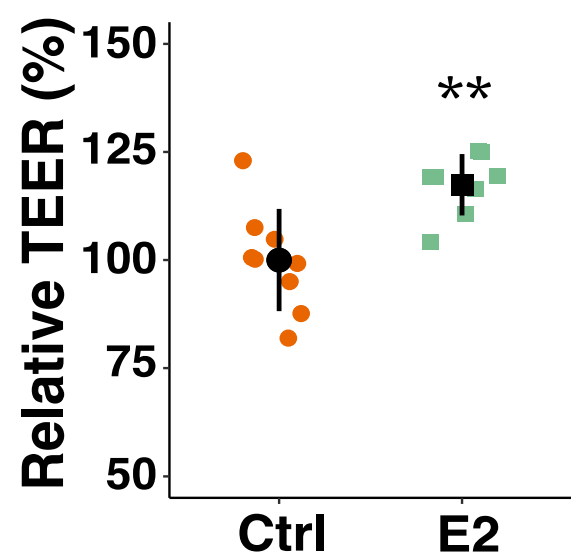

Figure 9. Estradiol increases barrier function in endothelial cells (ECs) in presence of pericytes (PCs). Endothelial cells were grown on permeable transwell inserts alone (a) or in co-culture with PCs on the opposite site of the porous membrane $(\mathbf{b})$. Cells were treated with estradiol $\left(\mathrm{E} 2,10^{-8} \mathrm{M}\right)$ or vehicle (Ctrl, DMSO) for $48 \mathrm{~h}$ and barrier function was measured by means of transendothelial electric resistance measurements with a cellZscope instrument. Experiments were performed 3 times in triplicates or duplicates and data represent mean $+/-$ sd. ns $p>0.05,{ }^{* *} p<0.01$, compared to Ctrl.

Table 2. Differentially regulated genes involved in migration and/or barrier function in estradioland control-treated pericytes that were co-cultured with endothelial cells.

\begin{tabular}{cccc}
\hline Gene & Gene Description & $\begin{array}{c}\text { Log2 FC } \\
\text { (Co- vs. } \\
\text { Mono-Culture) }\end{array}$ & FDR $\boldsymbol{p}$-Value \\
\hline TARSL2 [68] & Threonyl-tRNA & 2.7 & 0.335 \\
BEND6 [69,70] & synthetase-like 2 & 2.3 & 0.335 \\
HIST1H3I [71-73] & HEN domain containing 6 & -3.3 & 0.335 \\
HIST1H4D [71-73] & Histone cluster 1, H3i & -2.0 & 0.335 \\
\hline
\end{tabular}

Fold changes (FC) and adjusted $p$-values (FDR $p$-value) are depicted in the third and fourth column, respectively. Transcriptome Analysis Console (TAC, Applied Biosystems) was used for analyzing gene expression data of E2 treated vs. DMSO treated PCs in triplicates. For the analysis, a fold change (FC) cut-off of $+/-2$ and FDR $p$-Value of 0.34 was applied. 


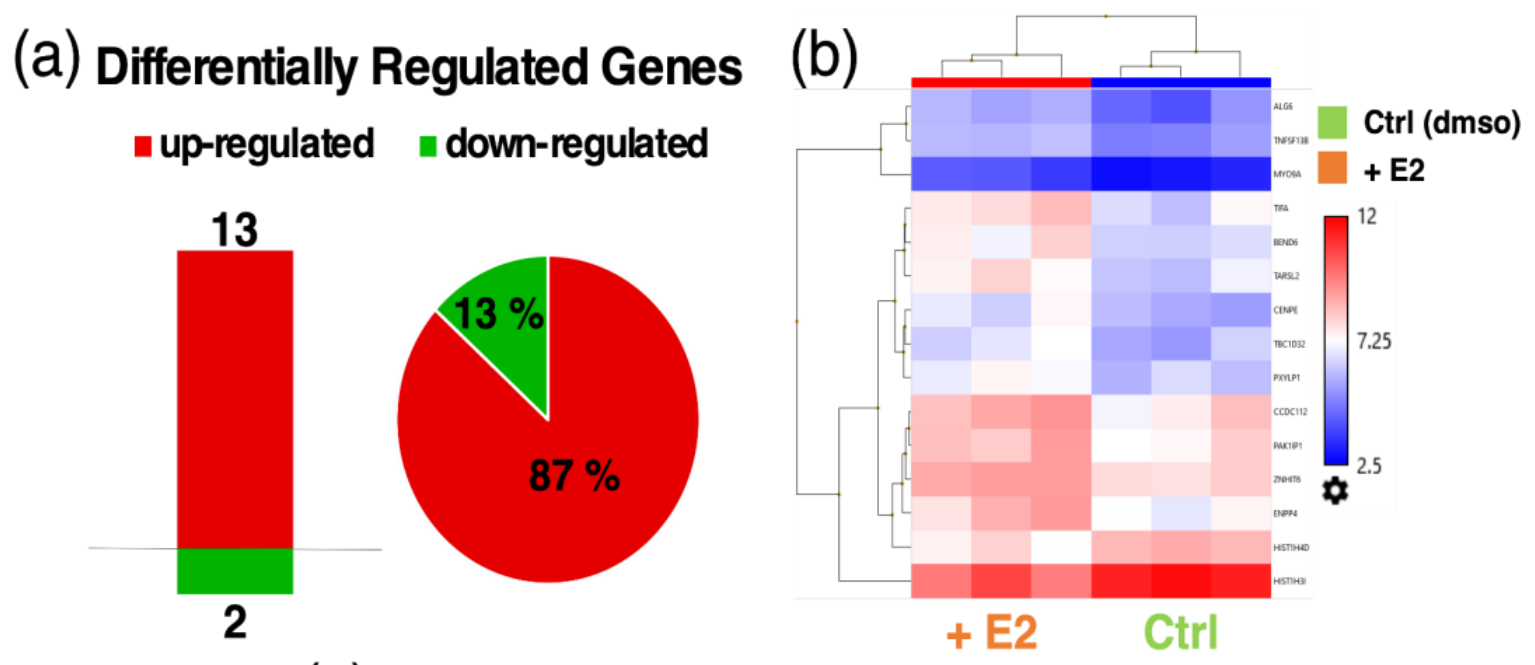

(c) P-val vs. Fold Change

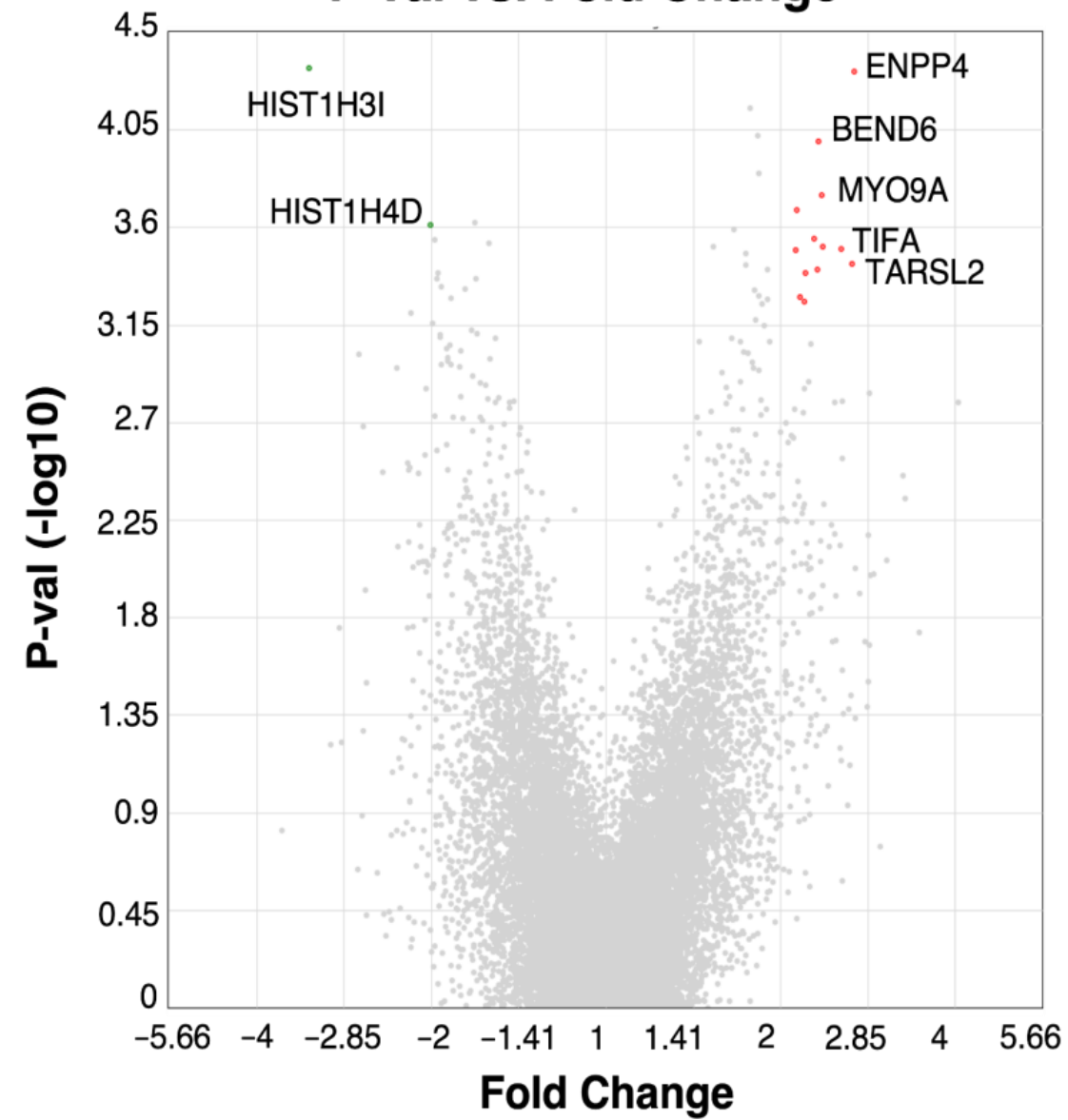

Figure 10. Differentially regulated genes (DRGs) in pericytes (PCs) co-cultured with endothelial cells treated with and without estradiol (E2, $\left.10^{-8} \mathrm{M}\right)$. Number of DRGs and pie chart representation of up- and downregulated genes in \% of total number of DRGs (a). Heatmap representation of DRGs between E2- and vehicle (dmso) treated PCs (b). Volcano plot showing p-value $(-\log 10)$ on the $y$-axis vs. fold change of DRGs on the $x$-axis and the most highly regulated genes are labeled (c). Color code: red-upregulated genes; green-downregulated genes. Transcriptome Analysis Console (TAC, Applied Biosystems by Thermo Fisher Scientific Inc, Waltham, MA, USA) was used for analyzing gene expression data of E2 treated vs. dmso treated PCs in triplicates. For the analysis, a fold change (FC) cut-off of $+/-2(\log 2 \mathrm{FC}+/-1)$ and FDR $p$-Value of 0.34 was applied. 


\section{Discussion}

The protective effects of estrogen on the neurovascular system have extensively been investigated, but mainly with regard to its action on endothelial cells (ECs) and vascular smooth muscle cells (VSMCs), while modulatory effects on pericytes (PCs) were not taken into account. Blood-brain barrier (BBB) disruption is a prominent pathological feature of many different neurovascular disorders, including stroke $[5,74]$. Since conflicting results regarding effects of estrogen on endothelial barrier integrity have been noticed in the past $[6,10,12,13]$, we hypothesized that PCs might contribute to estrogen's neuroprotective effects observed in many in vivo as well as clinical and observational studies. The present work demonstrates a novel potential mechanism of estrogen's neuroprotective action by regulating PC migration.

The expression of estrogen receptors (ERs) has been investigated and confirmed in various regions of the brain in different cell types like ECs, neurons, glial cells as well as astrocytes [75-78]. However, to the best of our knowledge, their expression in PCs remains unknown. We showed for the first time the expression of all three ERs (ER- $\alpha$, ER- $\beta$ and GPER) in human brain PCs on the protein level. Additionally, during our search we found no publications regarding the direct effects of estrogen on PC function, thereby making the findings of the present study unique.

In order to investigate the effects of estrogen action on PC function, we assessed cell proliferation and migration after E2 treatment. E2 is the most potent of the three main estrogens estrone (E1), estradiol (E2) and estriol (E3) [79] and most often used when investigating effects of estrogens in vitro. In PCs treated with E2, we did not observe any effects on cell growth. As positive controls, we used fetal bovine serum (FBS) and PDGF-B, which are common inducers of cell growth in PCs [80]. Both, FBS and PDGF-B induced the growth of PCs. The possibility of a masking effect due to opposing effects of different ERs was also tested by using selective ER-agonists and can be excluded.

Many in vivo and in vitro studies have shown PC degeneration and migration away from the vascular wall acutely after traumatic brain injury, stroke and cerebral ischemia which is correlated with increased permeability of the vessels [30,42,81,82]. Our finding of reduced PC migration upon E2 treatment proposes a novel mechanism by which estrogen might inhibit this important step in disease progression. To highlight our finding also under pathological situations, we induced PC migration by the inflammatory cytokine tumor necrosis factor alpha $(\mathrm{TNF} \alpha)$, which is known to be upregulated in several diseases and associated with BBB breakdown in conditions such as ischemic stroke, meningitis and sepsis [83-87]. We have observed its disruptive effects on EC barrier function in our 2D BBB model with the human brain endothelial cell line hCMEC/D3 on porous transwell inserts, confirming what has been shown in other in vitro studies [88,89]. As early as $3 \mathrm{~h}$ after ischemic stroke, TNF $\alpha$ mRNA levels are increased and protein expression follows to rise at around $6 \mathrm{~h}$ post stroke [90]. Interestingly, we found that E2 stably inhibited TNF $\alpha$-induced migration of PCs. While the stimulatory effect of TNF $\alpha$ on PC migration has been shown before [91], the inhibitory role of E2 is a novel finding. The counteraction of estrogen and $\mathrm{TNF} \alpha$ signaling in the cardiovascular system has been investigated in several in vitro and in vivo studies [92-95], serving as support for our observation. For example, E2 inhibits $\mathrm{TNF} \alpha$-induced migration and proliferation of SMCs, which are phenotypically similar to PCs [21]. Moreover, different studies demonstrate downregulated TNF $\alpha$ gene transcription and protein expression by estrogens [95-97]. The fact that among cytokines, TNF $\alpha$ is one of the most potent inducer of inflammatory responses in PCs [86] highlights the importance of the observed antagonizing action of E2 on TNF $\alpha$-mediated changes in PC migration.

The molecular mechanism by which E2 inhibits TNF $\alpha$-induced migration involves repression of MAPK phosphorylation. Despite the fact that E2 reduced TNF $\alpha$-stimulated phosphorylation of AKT in PCs, inhibiting AKT phosphorylation with pharmacological inhibitors (triciribine and LY0294002) did not mimic the inhibitory effect of E2 on TNF $\alpha$ stimulated migration in PCs. The applied concentrations of the two inhibitors, however, drastically decreased AKT phosphorylation, demonstrating their inhibitory potency. In 
contrast to Akt inhibitors, PD98059, the pharmacological inhibitor for ERK1/2, significantly reduced $\mathrm{TNF} \alpha$-induced migration back to basal levels. Increased MAPK-phosphorylation has also been shown in another in vitro study to induce migration in PCs [98]. Furthermore, Takata et al. showed that TNF $\alpha$ induces PC migration via MMP-9 release, and that MMP-9 expression is increased via activation of the PI3K/AKT cascade and MAPK pathways [33]. However, no direct link between AKT-/MAPK-phosphorylation and induced migration was made in this study. Moreover, in rats, the neuroprotective effects of estradiol were linked to attenuated ERK1/2 activation in the ischemic brain [99]. While estrogen signaling is associated with increased phosphorylation of MAPK and AKT in endothelial cells, thereby promoting migration and proliferation, its action on the same kinase cascades in VSMC is just the opposite, with a resulting decrease in mitogenic function. Since PCs are phenotypically similar to VSMCs and seem to stem from the same cell lineage [21], our results fall in line with the previously mentioned observation of a decreased activity of these kinase-cascades upon E2 treatment in VSMCs.

Determining the involvement of ER subtypes is an important step for therapeutics development, since considerable differences exist with regard to function between the three subtypes and ER specificity in different tissues [100,101]. We therefore elucidated the involvement of ERs in mediating estrogen's inhibitory effects on PC migration and found ER- $\beta$ as well as ER- $\alpha$ to be responsible for the inhibition of TNF $\alpha$-induced PC migration by E2. Interestingly, ER- $\beta$ signaling is responsible for counteracting many other TNF $\alpha$-induced cellular changes by estrogen in vascular cells $[6,93,102-104]$. Nevertheless, we also observed participation of ER- $\alpha$ in suppressing the TNF $\alpha$-induced migration in PCs. There are, indeed, different studies showing that the neuroprotective effects of estrogen are mediated by ER- $\alpha$ or a combination of ER- $\alpha$ and ER- $\beta[105,106]$. This indicates that there might be different molecular mechanisms by which E2 exerts its anti-inflammatory effects in PCs.

The relevance of PCs with regard to BBB induction and/or protection by estrogen, is further demonstrated by our findings in EC barrier function studies. E2 improved barrier function in EC-PC co-cultures but had no effect on EC monolayers. While an investigation to the underlying cause of this observation was not in the scope of the present study, reduced migration of PCs might be one potential mechanism. Other possible explanations include reduced PC apoptosis, PC contraction or the regulation of signaling molecules between ECs and PCs by E2. Indeed, Glinskii et al. demonstrated effects of E2 on PDGF-B release by ECs which in turn impacts PC recruitment and vessel stabilization. To further gain insights into the intracellular mechanisms that may be involved, transcriptomics analysis was conducted on genes modulated by estradiol in PCs using microarrays. Interestingly in the list of highly regulated genes by estradiol, many were regulators of cell migration. Importantly, estradiol downregulated genes that are known to induce cell migration and upregulated those mediating inhibitory actions on migratory activity. In this context, estradiol down regulated: ZFYVE16, a FYVE zink finger family protein (also called endofin) that regulates cell adhesion and induces cell migration [46] by regulating TGF $\beta$ signaling pathway and is downregulated by ER- $\beta$ in cancer cells [47]; and epiregulin, which stimulates cell migration via MAPK activation [57]. Additionally, estradiol downregulated multiple other genes known to induce cell migration, i.e., B3GNT5, a sphingolipid metabolic enzyme [58]; FADS1 [44], MIR1908 (a cholesterol responsive miRNA [45]); nucleoporin 58 kDa (NUP58) [55]; TOPORS [53,54]; Six homeobox 4 [48]; Retinoblastoma binding protein-9 (RBBP9) [49].

Apart from downregulating genes that induce cell migration, treatment with estradiol upregulated some genes that are involved in cell survival and some are known to inhibit cell migration. In this context, estradiol upregulated: REXO4 or Xenopus gene which prevents mitotic catastrophe (XPMC2) and its human analog, hPMC2, regulate quinone reductase activity via ER- $\beta$ [59]. Activation of Quinone reductase regulates cell fate decisions during stress/oxidative injury. Importantly, knock down of NAD [P]:quinone oxidoreductase-1 aggravates cancer growth and cell migration [60]; NDUFAF6 or NADH 
dehydrogenase (ubiquinone) complex 1, assembly factor 6 which is the largest complex of the mitochondrial electron transport chain and known to inhibit cell migration and metastasis [61]. Other tumor suppressor genes which inhibit cell migration, metastasis, invasion and that were induced by estradiol in pericytes include GLIPR1L1 [64]; ZNF582AS1 (a novel lncRNA) [62]; DACT1 [63]. Additionally, estradiol upregulated: suprabasin (SBSN), a cell differentiation protein, knockdown of which has contractile effects on blood vessels [107], an effect associated with barrier disruption; NPR2 which mediates the neuroprotective actions of C-type natriuretic peptide against hypoxia-ischemia brain injury and regulates microcirculatory flow and blood pressure by acting on pericytes [108]; and VEGFC, a VEGF isoform which effects lymphatic vessels. VEGF also promotes pericyte growth and coverage of brain capillaries [109]. Together these observations suggest that estradiol largely induces anti-migratory mechanisms to protect and prevent barrier disruption, moreover, it upregulates mechanisms to maintain pericyte survival and well-being.

Although estradiol modulated multiple genes in PC monocultures, it significantly modulated fewer genes in pericytes co-cultured with endothelial cells. Within the upregulated genes TARSL2 [68] and BEND6 [69] have been shown to directly or indirectly inhibit migration/metastasis. Additionally, downregulation of BEND6, a nuclear antagonist of $\mathrm{NOTCH}$, has been observed following BBB disruption [70]. Interestingly, two histone associated genes HIST1H31 and HIST1H4D were downregulated and histone variants are known to facilitate cell motility/migration [71-73]. Taken together, our findings from the co-cultured system provide evidence that estradiol may induce its protective action against BBB disruption by preventing the migration of pericytes from endothelial basolateral surface and by increasing factors that promote BBB induction.

A limitation of this study is the pure in vitro character of the performed experiments. Since cell responses can substantially be affected by neighboring cell types, it is essential to verify the present findings also under in vivo conditions. Furthermore, the PCs used for conducting the experiments of this study were of male origin. Since genes expressed on sex chromosomes can have marked impacts on the function of cells, it would be important to perform these experiments also in female cells, in order to make conclusive statements [110]. Furthermore, since only two aspects of PC function have been addressed in this study, it would also be important to investigate the effect of estrogen on other aspects of cellular function such as cell viability under for example hypoxic conditions or in response to TNF $\alpha$ stimulation. Since E2 is a well-recognized inducer of nitric oxide (NO) in the vasculature, and $\mathrm{TNF} \alpha$ is associated with reduced endothelial nitric oxide synthase expression and a related decrease in vasorelaxation [97], potential modulatory effects of E2 on ischemiainduced changes in NO production in PCs would be an interesting approach to investigate additional mechanisms of estrogen-mediated neuroprotection.

In two recent publications [38,40], we have shown the modulatory effects of brain microvascular ECs and PCs on genes and BBB function. We also observed dramatic changes in interferon-associated genes and pro- as well as anti-inflammatory cytokines. Collectively, these changes resulted in improved BBB function. Since many of the altered genes were antiviral, together with the fact that capillary pericytes are damaged [111] and interferon levels are decreased in subjects with COVID [112], it is tempting to speculate that the estradiol may protect pericytes against TNF $\alpha$-induced damage and limit organ damage by preserving barrier function. This may potentially explain the gender based differences in COVID-induced organ damage, disease severity and mortality, where age-matched premenopausal women are protected compared to men, while this effect seems to be lost in postmenopausal women (unpublished findings, doi:10.1101/2020.07.30.20164921) [113]. It is feasible that estradiol may prevent capillary damage by upregulating antiviral mechanisms and preserving pericyte function. This contention is further supported by the fact that TNF $\alpha$ is significantly increased in COVID 19 subjects [114] and our findings that estradiol inhibits $\mathrm{TNF} \alpha$-induced migration of pericytes. 


\section{Conclusions}

In conclusion, the present study contributes to a better mechanistic understanding of estrogen's well-known anti-inflammatory and neuroprotective actions. Our findings postulate that estrogen receptor alpha and -beta signaling might lead to reduced PC detachment from the vessel wall in response to inflammatory stimuli by downregulation of cytokine-induced MAPK phosphorylation, thereby protecting BBB integrity and preventing a cascade of events leading to further aggravation of the condition.

Supplementary Materials: The following are available online at https:/ /www.mdpi.com/article/10.3 390/cells10092314/s1. Figure S1. Schematic representation of experimental set-up for the scratch/woundclosure assay. Figure S2. Estradiol (E2) has no impact on pericyte (PC) proliferation/platelet-derived growth factor (PDGF)-BB and fetal bovine serum (FBS) increase PC proliferation/ER-agonists have no effect on PC proliferation. Figure S3. FBS and PDGF-BB induce migration in pericytes (PCs). Figure S4. TNF $\alpha$ reduces barrier function of an endothelial monolayer in vitro. Figure S5. TNF $\alpha$ induces pericyte (PC) migration. Figure S6. Estrogen receptors ER- $\alpha$ and ER- $\beta$ are responsible for estrogen-mediated downregulation of pericyte migration. Figure S7. ER- $\alpha$ - and ER- $\beta$-antagonists block the effect of estradiol (E2) on pericyte (PC) migration. Table S1. Top ten downregulated genes in estradiol treated pericytes; Table S2. Upregulated genes in estradiol treated pericytes; Table S3. Differentially regulated genes (DRGs) in estradiol treated endothelial cells; Table S4. Differentially regulated gene (DRG) in endothelial cells (ECs) co-cultured with pericytes (PCs) and treated with estradiol; Table S5. Downregulated genes in estradiol treated pericytes co-cultured with endothelial cells on the opposite side of a transwell insert; Table S6. Top ten upregulated genes in estradiol treated pericytes co-cultured with endothelial cells on the opposite side of a transwell insert.

Author Contributions: Conceptualization, L.K. and R.K.D.; methodology, L.K., M.O. and R.K.D.; validation, L.K. and M.O.; formal analysis, L.K. and M.O.; investigation, L.K. and R.K.D.; resources, R.K.D.; writing — original draft preparation, L.K. and R.K.D.; writing—review and editing, L.K. and R.K.D.; visualization, L.K.; supervision, R.K.D.; project administration, R.K.D.; funding acquisition, R.K.D. All authors have read and agreed to the published version of the manuscript.

Funding: This research was funded by Swiss National Sciences Foundation 31003A-138067 (RKD); Uniscientia P100-2016 (RKD).

Institutional Review Board Statement: Not applicable.

Informed Consent Statement: Not applicable.

Data Availability Statement: All data supporting the findings of this study are available within the article and its supplemental data file or from the corresponding author upon reasonable request.

Acknowledgments: We thank Margit Henry and Tamara Rotshteyn from CMMC Gene Expression Affymetrix Facility, Cologne, Germany for microarray assays; and Pierre-Olivier Couraud (Institute COCHIN, Paris, France) for providing human Cerebral Microvascular Endothelial Cell line (hCMEC/D3).

Conflicts of Interest: The authors declare no conflict of interest. The funders had no role in the design of the study; in the collection, analyses, or interpretation of data; in the writing of the manuscript, or in the decision to publish the results. There is no conflict of interest, which could be perceived as prejudicing the impartiality of the research reported.

\section{References}

1. Demel, S.L.; Kittner, S.; Ley, S.H.; McDermott, M.; Rexrode, K.M. Stroke Risk Factors Unique to Women. Stroke 2018, 49, 518-523. [CrossRef]

2. Koellhoffer, E.C.; McCullough, L.D. The Effects of Estrogen in Ischemic Stroke. Transl. Stroke Res. 2013, 4, 390-401. [CrossRef]

3. Iorga, A.; Cunningham, C.M.; Moazeni, S.; Ruffenach, G.; Umar, S.; Eghbali, M. The protective role of estrogen and estrogen receptors in cardiovascular disease and the controversial use of estrogen therapy. Biol. Sex Differ. 2017, 8, 33. [CrossRef]

4. Xing, D.; Nozell, S.; Chen, Y.-F.; Hage, F.; Oparil, S. Estrogen and Mechanisms of Vascular Protection. Arter. Thromb. Vasc. Biol. 2009, 29, 289-295. [CrossRef] [PubMed]

5. Nadareishvili, Z.; Simpkins, A.N.; Hitomi, E.; Reyes, D.; Leigh, R. Post-Stroke Blood-Brain Barrier Disruption and Poor Functional Outcome in Patients Receiving Thrombolytic Therapy. Cerebrovasc. Dis. 2019, 47, 135-142. [CrossRef] [PubMed] 
6. Shin, J.; Yang, S.; Jeong, S.; Park, H.; Choi, Y.-H.; Park, E.-M. Activation of estrogen receptor $\beta$ reduces blood-brain barrier breakdown following ischemic injury. Neuroscience 2013, 235, 165-173. [CrossRef] [PubMed]

7. Burek, M.; Arias-Loza, P.A.; Roewer, N.; Forster, C.Y. Claudin-5 as a Novel Estrogen Target in Vascular Endothelium. Arter. Thromb. Vasc. Biol. 2010, 30, 298-304. [CrossRef]

8. Nadkarni, S.; McArthur, S. Oestrogen and immunomodulation: New mechanisms that impact on peripheral and central immunity. Curr. Opin. Pharmacol. 2013, 13, 576-581. [CrossRef]

9. Czlonkowska, A.; Ciesielska, A.; Gromadzka, G.; Kurkowska-Jastrzebska, I. Estrogen and Cytokines Production - The Possible Cause of Gender Differences in Neurological Diseases. Curr. Pharm. Des. 2005, 11, 1017-1030. [CrossRef] [PubMed]

10. Li, M.; Zhang, Z.; Sun, W.; Koehler, R.C.; Huang, J. 17ß-estradiol attenuates breakdown of blood-brain barrier and hemorrhagic transformation induced by tissue plasminogen activator in cerebral ischemia. Neurobiol. Dis. 2011, 44, 277-283. [CrossRef]

11. McCullough, L.D.; Hurn, P.D. Estrogen and ischemic neuroprotection: An integrated view. Trends Endocrinol. Metab. 2003, 14, 228-235. [CrossRef]

12. Gorodeski, G.I. Estrogen Decrease in Tight Junctional Resistance Involves Matrix-Metalloproteinase-7-Mediated Remodeling of Occludin. Endocrinology 2007, 148, 218-231. [CrossRef]

13. Groten, T.; Pierce, A.A.; Huen, A.C.; Schnaper, H.W. $17 \beta$-estradiol transiently disrupts adherens junctions in endothelial cells. FASEB J. 2005, 19, 1368-1370. [CrossRef]

14. Straub, R.H. The Complex Role of Estrogens in Inflammation. Endocr. Rev. 2007, 28, 521-574. [CrossRef] [PubMed]

15. Kuruca, S.E.; Karadenizli, S.; Akgun-Dar, K.; Kapucu, A.; Kaptan, Z.; Uzum, G. The effects of $17 \beta$-estradiol on blood brain barrier integrity in the absence of the estrogen receptor alpha; an in-vitro model. Acta Histochem. 2017, 119, 638-647. [CrossRef] [PubMed]

16. Gastfriend, B.D.; Palecek, S.P.; Shusta, E.V. Modeling the blood-brain barrier: Beyond the endothelial cells. Curr. Opin. Biomed. Eng. 2018, 5, 6-12. [CrossRef]

17. Armulik, A.; Genové, G.; Mäe, M.; Nisancioglu, M.H.; Wallgard, E.; Niaudet, C.; He, L.; Norlin, J.; Lindblom, P.; Strittmatter, K.; et al. Pericytes regulate the blood-brain barrier. Nature 2010, 468, 557-561. [CrossRef] [PubMed]

18. Daneman, R.; Zhou, L.; Kebede, A.A.; Barres, B.A. Pericytes are required for blood-brain barrier integrity during embryogenesis. Nat. Cell Biol. 2010, 468, 562-566. [CrossRef]

19. Zlokovic, B.V. The Blood-Brain Barrier in Health and Chronic Neurodegenerative Disorders. Neuron 2008, 57, 178-201. [CrossRef] [PubMed]

20. Michinaga, S.; Koyama, Y. Dual Roles of Astrocyte-Derived Factors in Regulation of Blood-Brain Barrier Function after Brain Damage. Int. J. Mol. Sci. 2019, 20, 571. [CrossRef]

21. Armulik, A.; Genové, G.; Betsholtz, C. Pericytes: Developmental, Physiological, and Pathological Perspectives, Problems, and Promises. Dev. Cell 2011, 21, 193-215. [CrossRef]

22. Trost, A.; Lange, S.; Schroedl, F.; Bruckner, D.; Motloch, K.A.; Bogner, B.; Kaser-Eichberger, A.; Strohmaier, C.; Runge, C.; Aigner, L.; et al. Brain and Retinal Pericytes: Origin, Function and Role. Front. Cell. Neurosci. 2016, 10, 20. [CrossRef]

23. Lendahl, U.; Nilsson, P.; Betsholtz, C. Emerging links between cerebrovascular and neurodegenerative diseases-a special role for pericytes. EMBO Rep. 2019, 20, e48070. [CrossRef]

24. Hall, C.; Reynell, C.; Gesslein, B.; Hamilton-Whitaker, N.; Mishra, A.; Sutherland, B.; O'Farrell, F.; Buchan, A.M.; Lauritzen, M.; Attwell, D. Capillary pericytes regulate cerebral blood flow in health and disease. Nat. Cell Biol. 2014, 508, 55-60. [CrossRef] [PubMed]

25. Sweeney, M.D.; Sagare, A.P.; Zlokovic, B.V. Blood-brain barrier breakdown in Alzheimer disease and other neurodegenerative disorders. Nat. Rev. Neurol. 2018, 14, 133-150. [CrossRef] [PubMed]

26. Laredo, F.; Plebanski, J.; Tedeschi, A. Pericytes: Problems and Promises for CNS Repair. Front. Cell. Neurosci. 2019, 13, 13. [CrossRef] [PubMed]

27. Ferland-McCollough, D.; Slater, S.; Richard, J.; Reni, C.; Mangialardi, G. Pericytes, an overlooked player in vascular pathobiology. Pharmacol. Ther. 2017, 171, 30-42. [CrossRef]

28. Nishioku, T.; Dohgu, S.; Takata, F.; Eto, T.; Ishikawa, N.; Kodama, K.; Nakagawa, S.; Yamauchi, A.; Kataoka, Y. Detachment of Brain Pericytes from the Basal Lamina is Involved in Disruption of the Blood-Brain Barrier Caused by Lipopolysaccharide-Induced Sepsis in Mice. Cell. Mol. Neurobiol. 2008, 29, 309-316. [CrossRef]

29. Eshaq, R.S.; Aldalati, A.M.; Alexander, J.S.; Harris, N.R. Diabetic retinopathy: Breaking the barrier. Pathophysiology 2017, 24, 229-241. [CrossRef]

30. Zehendner, C.M.; Sebastiani, A.; Hugonnet, A.; Bischoff, F.; Luhmann, H.J.; Thal, S.C. Traumatic brain injury results in rapid pericyte loss followed by reactive pericytosis in the cerebral cortex. Sci. Rep. 2015, 5, 13497. [CrossRef] [PubMed]

31. Geranmayeh, M.H.; Rahbarghazi, R.; Farhoudi, M. Targeting pericytes for neurovascular regeneration. Cell Commun. Signal. 2019, 17, 1-13. [CrossRef]

32. Tigges, U.; Boroujerdi, A.; Welser-Alves, J.V.; Milner, R. TNF- $\alpha$ promotes cerebral pericyte remodeling in vitro, via a switch from $\alpha 1$ to $\alpha 2$ integrins. J. Neuroinflamm. 2013, 10, 33. [CrossRef]

33. Takata, F.; Dohgu, S.; Matsumoto, J.; Takahashi, H.; Machida, T.; Wakigawa, T.; Harada, E.; Miyaji, H.; Koga, M.; Nishioku, T.; et al. Brain pericytes among cells constituting the blood-brain barrier are highly sensitive to tumor necrosis factor- $\alpha$, releasing matrix metalloproteinase-9 and migrating in vitro. J. Neuroinflamm. 2011, 8, 106. [CrossRef] 
34. Pan, W.; Kastin, A.J. Tumor necrosis factor and stroke: Role of the blood-brain barrier. Prog. Neurobiol. 2007, 83, 363-374. [CrossRef] [PubMed]

35. Clausen, B.H.; Wirenfeldt, M.; Høgedal, S.S.; Frich, L.H.; Nielsen, H.H.; Schrøder, H.D.; Østergaard, K.; Finsen, B.; Kristensen, B.W.; Lambertsen, K.L. Characterization of the TNF and IL-1 systems in human brain and blood after ischemic stroke. Acta Neuropathol. Commun. 2020, 8, 1-17. [CrossRef] [PubMed]

36. Mendelsohn, M.E.; Karas, R.H. The Protective Effects of Estrogen on the Cardiovascular System. N. Engl. J. Med. 1999, 340, 1801-1811. [CrossRef]

37. Gerrits, P.O.; de Weerd, H.; van der Want, J.; Kortekaas, R.; Luiten, P.G.; Veening, J.G. Microvascular changes in estrogen- $\alpha$ sensitive brainstem structures of aging female hamsters. Neurosci. Res. 2010, 67, 267-274. [CrossRef] [PubMed]

38. Kurmann, L.; Okoniewski, M.; Dubey, R. Transcryptomic Analysis of Human Brain -Microvascular Endothelial Cell Driven Changes in -Vascular Pericytes. Cells 2021, 10, 1784. [CrossRef]

39. Weksler, B.B.; Subileau, E.A.; Perrière, N.; Charneau, P.; Holloway, C.J.; Leveque, M.; Tricoire-Leignel, H.; Nicotra, A.; Bourdoulous, S.; Turowski, P.; et al. Blood-brain barrier-specific properties of a human adult brain endothelial cell line. FASEB J. 2005, 19, 1872-1874. [CrossRef]

40. Kurmann, L.; Okoniewski, M.; Ogunshola, O.O.; Leeners, B.; Imthurn, B.; Dubey, R.K. Transcryptomic Analysis of Human Brain-Microvascular Endothelial Response to -Pericytes: Cell Orientation Defines Barrier Function. Cells 2021, 10, 963. [CrossRef]

41. Melgar, M.A.; Rafols, J.; Gloss, D.; Diaz, F.G. Postischemic Reperfusion: Ultrastructural Blood-Brain Barrier and Hemodynamic Correlative Changes in an Awake Model of Transient Forebrain Ischemia. Neurosurgery 2005, 56, 571-581. [CrossRef] [PubMed]

42. Dore-Duffy, P.; Owen, C.; Balabanov, R.; Murphy, S.; Beaumont, T.; Rafols, J.A. Pericyte Migration from the Vascular Wall in Response to Traumatic Brain Injury. Microvasc. Res. 2000, 60, 55-69. [CrossRef] [PubMed]

43. Wright, J.L.; Merchant, R.E. Blood-brain barrier changes following intracerebral injection of human recombinant tumor necrosis factor-? in the rat. J. Neuro-Oncol. 1994, 20, 17-25. [CrossRef] [PubMed]

44. Zhao, R.; Tian, L.; Zhao, B.; Sun, Y.; Cao, J.; Chen, K.; Li, F.; Li, M.; Shang, D.; Liu, M. FADS1 promotes the progression of laryngeal squamous cell carcinoma through activating AKT/mTOR signaling. Cell Death Dis. 2020, 11, 272. [CrossRef]

45. Xia, X.; Li, Y.; Wang, W.; Tang, F.; Tan, J.; Sun, L.; Li, Q.; Sun, L.; Tang, B.; He, S. MicroRNA-1908 functions as a glioblastoma oncogene by suppressing PTEN tumor suppressor pathway. Mol. Cancer 2015, 14, 154. [CrossRef]

46. Paek, A.R.; You, H.J.; Lee, C.-H. A role of zinc-finger protein 143 for cancer cell migration and invasion through ZEB1 and E-cadherin in colon cancer cells. Mol. Carcinog. 2013, 53, E161-E168. [CrossRef]

47. Indukuri, R.; Jafferali, M.H.; Song, D.; Damdimopoulos, A.; Hases, L.; Zhao, C.; Archer, A.; Williams, C. Genome-wide estrogen receptor $\beta$ chromatin binding in human colon cancer cells reveals its tumor suppressor activity. Int. J. Cancer 2021, 149, 692-706. [CrossRef] [PubMed]

48. Sun, X.; Ma, J.; Chen, Q.; Hou, Z.; Luo, X.; Wang, G.; Wang, J.; Hu, J.; Cao, Z. SIX4 promotes metastasis through STAT3 activation in breast cancer. Am. J. Cancer Res. 2020, 10, 224-236. [PubMed]

49. Shields, D.J.; Niessen, S.; Murphy, E.A.; Mielgo, A.; Desgrosellier, J.S.; Lau, S.K.M.; Barnes, L.A.; Lesperance, J.; Bouvet, M.; Tarin, D.; et al. RBBP9: A tumor-associated serine hydrolase activity required for pancreatic neoplasia. Proc. Natl. Acad. Sci. USA 2010, 107, 2189-2194. [CrossRef]

50. Chen, S.-L.; Zhu, Z.-X.; Yang, X.; Liu, L.-L.; He, Y.-F.; Yang, M.-M.; Guan, X.-Y.; Wang, X.; Yun, J.-P. Cleavage and Polyadenylation Specific Factor 1 Promotes Tumor Progression via Alternative Polyadenylation and Splicing in Hepatocellular Carcinoma. Front. Cell Dev. Biol. 2021, 9, 616835. [CrossRef]

51. Mansour, M.A. SP3 is associated with migration, invasion, and Akt/PKB signalling in MDA-MB-231 breast cancer cells. J. Biochem. Mol. Toxicol. 2021, 35, e22657. [CrossRef]

52. Clayton, N.S.; Ridley, A.J. Targeting Rho GTPase Signaling Networks in Cancer. Front. Cell Dev. Biol. 2020, 8, 8. [CrossRef] [PubMed]

53. Ji, L.; Huo, X.; Zhang, Y.; Yan, Z.; Wang, Q.; Wen, B. TOPORS, a tumor suppressor protein, contributes to the maintenance of higher-order chromatin architecture. Biochim. Biophys. Acta (BBA) Bioenerg. 2020, 1863, 194518. [CrossRef]

54. Fu, Y.; Katsaros, D.; Biglia, N.; Wang, Z.; Pagano, I.; Tius, M.; Tiirikainen, M.; Rosser, C.; Yang, H.; Yu, H. Vitamin D receptor upregulates lncRNA TOPORS-AS1 which inhibits the Wnt/ $\beta$-catenin pathway and associates with favorable prognosis of ovarian cancer. Sci. Rep. 2021, 11, 7484. [CrossRef]

55. Shi, J.; Li, C.; Wang, H.; Xiao, B.; Qiu, W. NUP58 facilitates metastasis and epithelial-mesenchymal transition of lung adenocarcinoma via the GSK-3 beta/Snail signaling pathway. Am. J. Transl. Res. 2019, 11, 393-405.

56. Li, X.; Liang, L.; Huang, L.; Ma, X.; Li, D.; Cai, S. High expression of protein phosphatase 4 is associated with the aggressive malignant behavior of colorectal carcinoma. Mol. Cancer 2015, 14, 95. [CrossRef] [PubMed]

57. Cao, Y.; Wang, L.; Yang, H.; Lin, X.; Li, G.; Han, N.; Du, J.; Fan, Z. Epiregulin promotes the migration and chemotaxis ability of adipose-derived mesenchymal stem cells via mitogen-activated protein kinase signaling pathways. J. Cell. Biochem. 2018, 119, 8450-8459. [CrossRef] [PubMed]

58. Meng, Q.; Hu, X.; Zhao, X.; Kong, X.; Meng, Y.-M.; Chen, Y.; Su, L.; Jiang, X.; Qiu, X.; Huang, C.; et al. A circular network of coregulated sphingolipids dictates lung cancer growth and progression. EBioMedicine 2021, 66, 103301. [CrossRef] [PubMed]

59. Krishnamurthy, N.; Ngam, C.R.; Berdis, A.J.; Montano, M.M. The exonuclease activity of hPMC2 is required for transcriptional regulation of the QR gene and repair of estrogen-induced abasic sites. Oncogene 2011, 30, 4731-4739. [CrossRef] 
60. Thapa, D.; Huang, S.-B.; Muñoz, A.R.; Yang, X.; Bedolla, R.G.; Hung, C.-N.; Chen, C.-L.; Huang, T.H.-M.; Liss, M.A.; Reddick, R.L.; et al. Attenuation of NAD $[\mathrm{P}] \mathrm{H}:$ quinone oxidoreductase 1 aggravates prostate cancer and tumor cell plasticity through enhanced TGF $\beta$ signaling. Commun. Biol. 2020, 3, 12. [CrossRef] [PubMed]

61. Urra, F.A.; Muñoz, F.; Lovy, A.; Cárdenas, C. The Mitochondrial Complex(I)ty of Cancer. Front. Oncol. 2017, 7, 118. [CrossRef]

62. Yang, W.; Zhang, K.; Li, L.; Xu, Y.; Ma, K.; Xie, H.; Zhou, J.; Cai, L.; Gong, Y.; Gong, K. Correction to: Downregulation of lncRNA ZNF582-AS1 due to DNA hypermethylation promotes clear cell renal cell carcinoma growth and metastasis by regulating the N(6)-methyladenosine modification of MT-RNR1. J. Exp. Clin. Cancer Res. 2021, 40, 92. [CrossRef] [PubMed]

63. Yang, J.-H.; Lin, L.-K.; Zhang, S. Effects of DACT1 methylation status on invasion and metastasis of nasopharyngeal carcinoma. Biol. Res. 2019, 52, 31. [CrossRef]

64. Ren, C.; Ren, C.-H.; Li, L.; Goltsov, A.A.; Thompson, T.C. Identification and characterization of RTVP1/GLIPR1-like genes, a novel p53 target gene cluster. Genome 2006, 88, 163-172. [CrossRef]

65. Hayashi, K.; Nakao, S.; Nakaoke, R.; Nakagawa, S.; Kitagawa, N.; Niwa, M. Effects of hypoxia on endothelial/pericytic co-culture model of the blood-brain barrier. Regul. Pept. 2004, 123, 77-83. [CrossRef]

66. Hori, S.; Ohtsuki, S.; Hosoya, K.-I.; Nakashima, E.; Terasaki, T. A pericyte-derived angiopoietin-1 multimeric complex induces occludin gene expression in brain capillary endothelial cells through Tie-2 activation in vitro. J. Neurochem. 2004, 89, 503-513. [CrossRef] [PubMed]

67. Stone, N.L.; England, T.J.; O'Sullivan, S.E. A Novel Transwell Blood Brain Barrier Model Using Primary Human Cells. Front. Cell. Neurosci. 2019, 13, 230. [CrossRef] [PubMed]

68. Liu, Y.; Jiang, K.; Zhi, T.; Xu, X. miR-720 is a key regulator of glioma migration and invasion by controlling TARSL2 expression. Hum. Cell 2021, 1-13. [CrossRef]

69. Dai, Q.; Andreu-Agullo, C.; Insolera, R.; Wong, L.C.; Shi, S.-H.; Lai, E.C. BEND6 is a nuclear antagonist of Notch signaling during self-renewal of neural stem cells. Development 2013, 140, 1892-1902. [CrossRef]

70. Mao, X.W.; Nishiyama, N.C.; Byrum, S.D.; Stanbouly, S.; Jones, T.; Holley, J.; Sridharan, V.; Boerma, M.; Tackett, A.J.; Willey, J.S.; et al. Spaceflight induces oxidative damage to blood-brain barrier integrity in a mouse model. FASEB J. 2020, 34, 15516-15530. [CrossRef] [PubMed]

71. Chen, L.; Yang, F.; Li, T.; Xiao, P.; Han, Z.-J.; Shu, L.-F.; Yuan, Z.-Z.; Liu, W.-J.; Long, Y.-Q. Extracellular Histone Promotes Prostate Cancer Migration and Epithelial-Mesenchymal Transition through NF-кB-Mediated Inflammatory Responses. Chemotherapy 2019, 64, 177-186. [CrossRef]

72. Ilter, D.; Blenis, J.; Gomes, A.P. Histone H3 variants at the root of metastasis. Mol. Cell. Oncol. 2020, 7, 1684128. [CrossRef]

73. Markouli, M.; Strepkos, D.; Basdra, E.K.; Papavassiliou, A.G.; Piperi, C. Prominent Role of Histone Modifications in the Regulation of Tumor Metastasis. Int. J. Mol. Sci. 2021, 22, 2778. [CrossRef]

74. Jiang, X.; Andjelkovic, A.V.; Zhu, L.; Yang, T.; Bennett, M.V.L.; Chen, J.; Keep, R.F.; Shi, Y. Blood-brain barrier dysfunction and recovery after ischemic stroke. Prog. Neurobiol. 2018, 163-164, 144-171. [CrossRef] [PubMed]

75. O'Dowd, B.F.; Nguyen, T.; Marchese, A.; Cheng, R.; Lynch, K.R.; Heng, H.H.; Kolakowski, L.F.; George, S.R. Discovery of Three Novel G-Protein-Coupled Receptor Genes. Genome 1998, 47, 310-313. [CrossRef]

76. Almey, A.; Milner, T.A.; Brake, W.G. Estrogen receptors in the central nervous system and their implication for dopaminedependent cognition in females. Horm. Behav. 2015, 74, 125-138. [CrossRef] [PubMed]

77. Guo, J.; Krause, D.N.; Horne, J.; Weiss, J.; Li, X.; Duckles, S.P. Estrogen-Receptor-Mediated Protection of Cerebral Endothelial Cell Viability and Mitochondrial Function after Ischemic Insult in vitro. Br. J. Pharmacol. 2009, 30, 545-554. [CrossRef]

78. Kuiper, G.G.; Shughrue, P.J.; Merchenthaler, I.; Gustafsson, J.A. The Estrogen Receptor $\beta$ Subtype: A Novel Mediator of Estrogen Action in Neuroendocrine Systems. Front. Neuroendocr. 1998, 19, 253-286. [CrossRef]

79. Watson, C.S.; Jeng, Y.; Kochukov, M. Nongenomic actions of estradiol compared with estrone and estriol in pituitary tumor cell signaling and proliferation. FASEB J. 2008, 22, 3328-3336. [CrossRef]

80. Xiang, D.; Feng, Y.; Wang, J.; Zhang, X.; Shen, J.; Zou, R.; Yuan, Y. Platelet-derived growth factor-BB promotes proliferation and migration of retinal microvascular pericytes by up-regulating the expression of C-X-C chemokine receptor types 4 . Exp. Ther. Med. 2019, 18, 4022-4030. [CrossRef]

81. Milesi, S.; Boussadia, B.; Plaud, C.; Catteau, M.; Rousset, M.-C.; De Bock, F.; Schaeffer, M.; Lerner-Natoli, M.; Rigau, V.; Marchi, N. Redistribution of PDGFR $\beta$ cells and NG2DsRed pericytes at the cerebrovasculature after status epilepticus. Neurobiol. Dis. 2014, 71, 151-158. [CrossRef] [PubMed]

82. Fernández-Klett, F.; Potas, J.; Hilpert, D.; Blazej, K.; Radke, J.; Huck, J.; Engel, O.; Stenzel, W.; Genové, G.; Priller, J. Early Loss of Pericytes and Perivascular Stromal Cell-Induced Scar Formation after Stroke. Br. J. Pharmacol. 2012, 33, 428-439. [CrossRef] [PubMed]

83. Bokhari, F.A.; Shakoori, T.; Butt, A.; Ghafoor, F. TNF-alpha: A risk factor for ischemic stroke. J. Ayub Med Coll. Abbottabad 2015, 26, 111-114.

84. Wilkins, H.M.; Swerdlow, R.H. TNF $\alpha$ in cerebral ischemia: Another stroke against you? J. Neurochem. 2015, 132, 369-372. [CrossRef] [PubMed]

85. Cheng, X.; Shen, Y.; Li, R. Targeting TNF: A therapeutic strategy for Alzheimer's disease. Drug Discov. Today 2014, 19, 1822-1827. [CrossRef] 
86. Smyth, L.C.D.; Rustenhoven, J.; Park, T.I.-H.; Schweder, P.; Jansson, D.; Heppner, P.A.; O'Carroll, S.J.; Mee, E.W.; Faull, R.L.M.; Curtis, M.; et al. Unique and shared inflammatory profiles of human brain endothelia and pericytes. J. Neuroinflamm. 2018, 15, 138. [CrossRef]

87. Candelario-Jalil, E.; Taheri, S.; Yang, Y.; Sood, R.; Grossetete, M.; Estrada, E.Y.; Fiebich, B.L.; Rosenberg, G.A. Cyclooxygenase Inhibition Limits Blood-Brain Barrier Disruption following Intracerebral Injection of Tumor Necrosis Factor- $\alpha$ in the Rat. J. Pharmacol. Exp. Ther. 2007, 323, 488-498. [CrossRef]

88. Rochfort, K.; Collins, L.E.; McLoughlin, A.; Cummins, P.M. Tumour necrosis factor- $\alpha$-mediated disruption of cerebrovascular endothelial barrier integrity in vitro involves the production of proinflammatory interleukin-6. J. Neurochem. 2016, 136, 564-572. [CrossRef] [PubMed]

89. Chen, A.Q.; Fang, Z.; Chen, X.L.; Yang, S.; Zhou, Y.F.; Mao, L.; Xia, Y.P.; Jin, H.J.; Li, Y.N.; You, M.F.; et al. Microglia-derived TNF- $\alpha$ mediates endothelial necroptosis aggravating blood brain-barrier disruption after ischemic stroke. Cell Death Dis. 2019, 10, 487. [CrossRef]

90. Liu, T.; Clark, R.K.; McDonnell, P.C.; Young, P.R.; White, R.F.; Barone, F.C.; Feuerstein, G.Z. Tumor necrosis factor-alpha expression in ischemic neurons. Stroke 1994, 25, 1481-1488. [CrossRef]

91. Welser-Alves, J.V.; Boroujerdi, A.; Tigges, U.; Milner, R. Analysis of TNF-alpha-Mediated Cerebral Pericyte Remodeling. Adv. Struct. Saf. Stud. 2014, 1155, 81-93. [CrossRef]

92. Florian, M.; Florianova, L.; Hussain, S.; Magder, S. Interaction of Estrogen and Tumor Necrosis Factor $\alpha$ in Endothelial Cell Migration and Early Stage of Angiogenesis. Endothelium 2008, 15, 265-275. [CrossRef] [PubMed]

93. Fortini, F.; Sega, F.V.D.; Caliceti, C.; Aquila, G.; Pannella, M.; Pannuti, A.; Miele, L.; Ferrari, R.; Rizzo, P. Estrogen receptor $\beta$-dependent Notch1 activation protects vascular endothelium against tumor necrosis factor $\alpha$ (TNF $\alpha$ )-induced apoptosis. J. Biol. Chem. 2017, 292, 18178-18191. [CrossRef]

94. Li, H.; Cheng, Y.; Simoncini, T.; Xu, S. 17 $\beta$-Estradiol inhibits TNF- $\alpha$-induced proliferation and migration of vascular smooth muscle cells via suppression of TRAIL. Gynecol. Endocrinol. 2016, 32, 581-586. [CrossRef]

95. Ito, A.; Bebo, B.F.; Matejuk, A.; Zamora, A.; Silverman, M.; Fyfe-Johnson, A.; Offner, H. Estrogen Treatment Down-Regulates TNF- $\alpha$ Production and Reduces the Severity of Experimental Autoimmune Encephalomyelitis in Cytokine Knockout Mice. J. Immunol. 2001, 167, 542-552. [CrossRef] [PubMed]

96. An, J.; Ribeiro, R.C.J.; Webb, P.; Gustafsson, J.-Å.; Kushner, P.J.; Baxter, J.D.; Leitman, D.C. Estradiol repression of tumor necrosis factor-alpha transcription requires estrogen receptor activation function-2 and is enhanced by coactivators. Proc. Natl. Acad. Sci. USA 1999, 96, 15161-15166. [CrossRef]

97. Arenas, I.A.; Armstrong, S.J.; Xu, Y.; Davidge, S.T. Chronic Tumor Necrosis Factor- $\alpha$ Inhibition Enhances NO Modulation of Vascular Function in Estrogen-Deficient Rats. Hypertension 2005, 46, 76-81. [CrossRef]

98. Zhang, Y.; Zhang, Y.; Bai, Y.; Chao, J.; Hu, G.; Chen, X.; Yao, H. Involvement of PUMA in pericyte migration induced by methamphetamine. Exp. Cell Res. 2017, 356, 28-39. [CrossRef]

99. Xiao, H.; Deng, M.; Yang, B.; Hu, Z.; Tang, J. Pretreatment with $17 \beta$-Estradiol Attenuates Cerebral Ischemia-Induced Blood-Brain Barrier Disruption in Aged Rats: Involvement of Antioxidant Signaling. Neuroendocrinology 2017, 106, 20-29. [CrossRef]

100. Cvoro, A.; Tatomer, D.; Tee, M.-K.; Zogovic, T.; Harris, H.A.; Leitman, D.C. Selective estrogen receptor- $\beta$ agonists repress transcription of proinflammatory genes. J. Immunol. 2008, 180, 630-636. [CrossRef]

101. Tiwari-Woodruff, S.K.; Morales, L.B.; Lee, R.R.; Voskuhl, R.R. Differential neuroprotective and anti-inflammatory effects of estrogen receptor ligands. J. Neurochem. 2007, 102, 140.

102. Xing, D.; Feng, W.; Miller, A.P.; Weathington, N.M.; Chen, Y.-F.; Novak, L.; Blalock, J.E.; Oparil, S. Estrogen modulates TNF- $\alpha-$ induced inflammatory responses in rat aortic smooth muscle cells through estrogen receptor- $\beta$ activation. Am. J. Physiol. Circ. Physiol. 2007, 292, H2607-H2612. [CrossRef]

103. Maggioli, E.; McArthur, S.; Mauro, C.; Kieswich, J.; Kusters, D.; Reutelingsperger, C.; Yaqoob, M.; Solito, E. Estrogen protects the blood-brain barrier from inflammation-induced disruption and increased lymphocyte trafficking. Brain Behav. Immun. 2016, 51, 212-222. [CrossRef]

104. Vaccari, J.P.D.R.; Bramlett, H.M.; Perez-Pinzon, M.A.; Raval, A.P. Estrogen preconditioning: A promising strategy to reduce inflammation in the ischemic brain. Cond. Med. 2019, 2, 106-113.

105. Asl, S.Z.; Khaksari, M.; Khachki, A.S.; Shahrokhi, N.; Nourizade, S. Contribution of estrogen receptors alpha and beta in the brain response to traumatic brain injury. J. Neurosurg. 2013, 119, 353-361. [CrossRef] [PubMed]

106. Spence, R.D.; Wisdom, A.; Cao, Y.; Hill, H.M.; Mongerson, C.R.L.; Stapornkul, B.; Itoh, N.; Sofroniew, M.V.; Voskuhl, R.R. Estrogen Mediates Neuroprotection and Anti-Inflammatory Effects during EAE through ER Signaling on Astrocytes But Not through ER Signaling on Astrocytes or Neurons. J. Neurosci. 2013, 33, 10924-10933. [CrossRef] [PubMed]

107. Kenagy, R.D.; Civelek, M.; Kikuchi, S.; Chen, L.; Grieff, A.; Sobel, M.; Lusis, A.J.; Clowes, A.W. Scavenger receptor class A member 5 ( SCARA5 ) and suprabasin ( SBSN) are hub genes of coexpression network modules associated with peripheral vein graft patency. J. Vasc. Surg. 2015, 64, 202-209.e6. [CrossRef]

108. Špiranec, K.; Chen, W.; Werner, F.; Nikolaev, V.O.; Naruke, T.; Koch, F.; Werner, A.; Eder-Negrin, P.; Diéguez-Hurtado, R.; Adams, R.H.; et al. Endothelial C-Type Natriuretic Peptide Acts on Pericytes to Regulate Microcirculatory Flow and Blood Pressure. Circulation 2018, 138, 494-508. [CrossRef] 
109. Zechariah, A.; ElAli, A.; Doeppner, T.R.; Jin, F.; Hasan, M.R.; Helfrich, I.; Mies, G.; Hermann, D.M. Vascular Endothelial Growth Factor Promotes Pericyte Coverage of Brain Capillaries, Improves Cerebral Blood Flow During Subsequent Focal Cerebral Ischemia, and Preserves the Metabolic Penumbra. Stroke 2013, 44, 1690-1697. [CrossRef]

110. Shah, K.; McCormack, C.E.; Bradbury, N.A. Do you know the sex of your cells? Am. J. Physiol. Cell Physiol. 2014, 306, C3-C18. [CrossRef] [PubMed]

111. Cardot-Leccia, N.; Hubiche, T.; Dellamonica, J.; Burel-Vandenbos, F.; Passeron, T. Pericyte alteration sheds light on microvasculopathy in COVID-19 infection. Intensiv. Care Med. 2020, 46, 1777-1778. [CrossRef] [PubMed]

112. Galani, I.-E.; Rovina, N.; Lampropoulou, V.; Triantafyllia, V.; Manioudaki, M.; Pavlos, E.; Koukaki, E.; Fragkou, P.C.; Panou, V.; Rapti, V.; et al. Untuned antiviral immunity in COVID-19 revealed by temporal type I/III interferon patterns and flu comparison. Nat. Immunol. 2021, 22, 32-40. [CrossRef] [PubMed]

113. O'Brien, J.; Du, K.Y.; Peng, C. Incidence, clinical features, and outcomes of COVID-19 in Canada: Impact of sex and age. J. Ovarian Res. 2020, 13, 137. [CrossRef] [PubMed]

114. Del Valle, D.M.; Kim-Schulze, S.; Huang, H.-H.; Beckmann, N.D.; Nirenberg, S.; Wang, B.; Lavin, Y.; Swartz, T.H.; Madduri, D.; Stock, A.; et al. An inflammatory cytokine signature predicts COVID-19 severity and survival. Nat. Med. 2020, 26, 1636-1643. [CrossRef] 